\title{
Urban Land and Housing Markets in the Punjab, Pakistan
}

\author{
Final Report
}

\author{
June 15, 2006
}

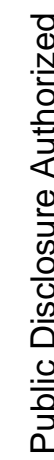

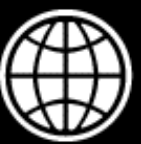

The World Bank

Infrastructure and Energy Department

South Asia Region 


\section{Acknowledgements}

This report was prepared by a team comprising Peter Ellis, David Dowall, Laura Vecvagare, Soraya Goga, Shahnaz Arshad and Richard Clifford. Sonia Hammam provided managerial guidance. The peer reviewers are Robert Buckley and Mila Freire.

We would to thank Government of Punjab for the assistance they provided the missions during the visits to the Punjab. 
Table of Contents

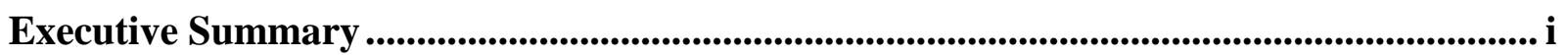

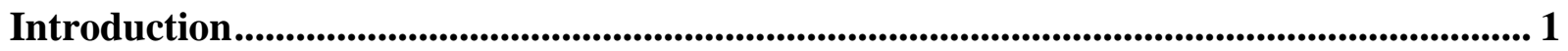

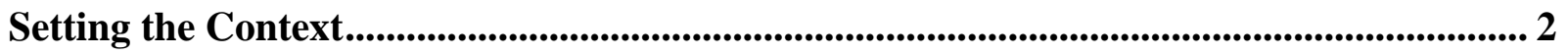

Characteristics of Well-Functioning Urban Land and Housing Markets............................ 4

The Punjab's Urban Land and Housing Markets are Not Performing Well...................... 5

What's Causing the Poor Performance? ................................................................................ 9

Subdivision and construction standards ................................................................ 16

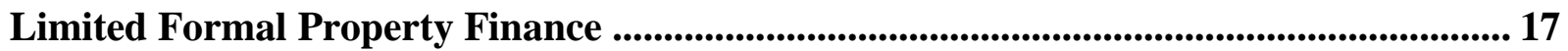

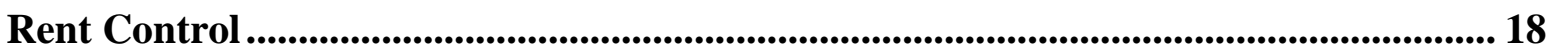

Complex Institutional Framework ................................................................................... 23

The public sector's response to the affordable housing shortfall has been in ineffective 24

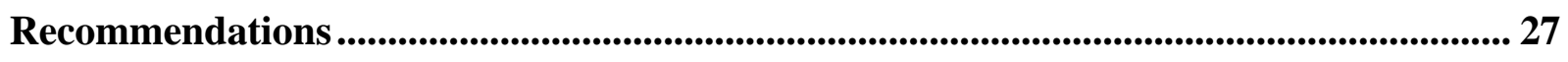

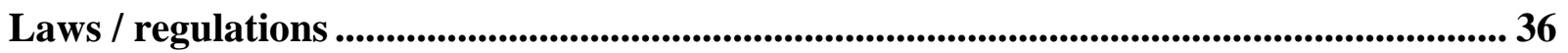




\section{Abbreviations}

$\begin{array}{ll}\text { ADS } & \text { Area Development Scheme } \\ \text { CBD } & \text { Center Business District } \\ \text { DDP } & \text { Development Data Platform (World Bank database) } \\ \text { FAR } & \text { Floor Area Ratio } \\ \text { GDP } & \text { Gross Domestic Product } \\ \text { HBFC } & \text { House Building Finance Corporation } \\ \text { IMPL } & \text { Integrated Master Plan of Lahore } \\ \text { LDA } & \text { Lahore Development Authority } \\ \text { LGO } & \text { Local Government Ordinance (2001) } \\ \text { NHP } & \text { National Housing Policy (2001) } \\ \text { PHA } & \text { Pakistan Housing Authority } \\ \text { PHATA } & \text { Punjab Housing \& Town Planning Agency } \\ \text { O\&M } & \text { Operation and Maintenance } \\ \text { Rs. } & \text { Pakistan Rupees } \\ \text { TMA } & \text { Tehsil Municipal Administration }\end{array}$




\section{Executive Summary}

Well-functioning urban land and housing markets are a critical success factors for achieving robust economic growth. This note provides a short overview of urban land and housing market performance in Punjab Province of Pakistan. It describes the characteristics of well-functioning urban land and housing markets and argues that, at present, the Punjab's urban land and housing markets are not performing well. The paper identifies a range of structural and institutional shortcomings that impede urban land market performance, and then concludes by offering recommendations for making land and housing markets function better.

Our review of key performance measures of the Punjab's urban land and housing marketsurban land supply, land prices, quality of the housing stock, access to urban services, construction costs, private sector participation in real estate development, and levels of informality in the housing production sector-indicate that the province's urban housing markets are not efficiently operating. This Background Study has pinpointed a range of impediments to efficient urban land and housing market performance: excessive public land ownership, inadequate infrastructure services, weak property rights, counterproductive urban planning policies and regulations, costly subdivision and construction regulations, limited financing for property development and acquisition, rent controls and distortive taxation mechanisms.

The study offers a series of recommendations for improving urban land market performance:

1. Build an urban information base and deepen understanding of urban land and property market dynamics.

2. Strengthen property rights and improve efficiency of land titling and registration.

3. Reform and restructure systems of local property taxation to reduce distortions and to strengthen resource mobilization.

4. Reform urban planning, zoning, subdivision and construction regulations to encourage sound economic development of cities and more affordable housing production.

5. Reform rent control.

6. Reduce levels of public land ownership through auctions and use proceeds to finance critical infrastructure and engage in a reform of public land development agencies.

7. Increase investment in infrastructure systems and build institutional base for economically and financial sustainable system of infrastructure delivery, operations and maintenance.

8. Encourage more private sector participation in real estate development and the financing of real estate. 
9. Design new institutional frameworks for managing urban development at the local, city and metropolitan levels.

As the governments of Pakistan and Punjab focus attention on the looming challenges posed by rapid urban development, reform efforts should be closely coordinated at the central, provincial and local levels of government. Governments at all levels should focus on the establishment of an enabling environment through strengthening the legal framework, particularly, for property rights, modernizing its planning, zoning and construction regulations and approaches, withdrawal from direct interventions in the market and facilitating greater involvement of the private sector. 


\section{Introduction}

1. The Punjab Province in Pakistan is in the midst of a profound urban transition, driven by structural economic change. The Punjab is transforming from an agriculturally-based economy to a manufacturing and service based economy, which is leading to massive urbanization. This transformation is just getting started and will continue over the next decade. According to the World Bank's Development Data Platform (DDP) database (2006), urban-based manufacturing and service sectors composed 77 percent of the Pakistan's GDP in 2003 and more than 90 percent of GDP growth during 1999 - 2003. As the Pakistan economy continues to expand and modernize, urbanization should continue at a strong pace over the next 5-10 years. Looking forward, one of the Punjab's key strategic issues is how well its cities function in order to drive overall economic growth.

2. Effectively managing the expansion of the Punjab's system of cities will largely determine how well the Punjab navigates this urban-based transition to manufacturing and services. Given its rapidity and scale, this expansion poses a major challenge for both Provincial and local governments. While urban population growth averaged 3.4 percent per year between 1981 and 1998, more recently it has more than doubled to 7 percent per year. In absolute terms, the Punjab's urban population increased from 12.9 million 1981 to 22.9 million in 1998 , and as of 2001 the Province's urban population stood at 28 million. Over the last twenty years, urban population growth in cities and urban areas of the Punjab increased by an average of about 750,000 persons per year. During the 1998-2001 period the annual average was much higher at 1.7 million per year.

3. To foster sustainable economic growth and reduce poverty, the Punjab's main urban centers need to accommodate additional urban growth and support economic development. A critical ingredient for success is well-functioning urban land and housing markets, which form the basis for both private sector growth and the ability to provide shelter to the population.

4. This background paper reviews and assesses how well the Punjab's urban land and housing markets are functioning. The evidence suggests that urban land and housing markets are not performing as well as they could. Urban land-use planning and development controls are impeding urban development, while land titling and registration systems hamper real estate

development. Systems of local resource mobilization and taxation do not generate sufficient revenues to fund key urban infrastructure. The paper notes the several critical negative consequences of poor urban land market performance, namely high land and housing prices, large and expanding katchi abadi developments, poorly located industrial estates, inadequate urban infrastructure, and constrained commercial development.

5. Without effective policy reform, the Punjab's cities will not expand in step with economic and demographic demand, land and housing prices will continue to remain expensive, and inefficient and unhealthy informal development will predominate. Ultimately, unless there is change, these urban land and housing market impediments are likely to constrain the Punjab's future economic development. 


\section{Setting the Context}

6. The importance of addressing housing and land issues is underlined by at least two factors, namely increasing urbanization and economic development. While the pace of urbanization in Punjab prior to 1998 has been slower than that in many other developing countries, recent population estimates suggest that urban growth in Punjab was double the Pakistan's average in urban areas and more than 5 times the province's general population growth during 1998-2001 (Table 1).

Table 1

Key Demographic Data for Pakistan and Punjab

\begin{tabular}{|l|l|l|}
\hline & Pakistan & Punjab \\
\hline Total population & & \\
\hline Million (2001) & $134^{\mathrm{a}}$ & 76 \\
\hline Average annual growth 1981-98 & $2.7 \%$ & $2.6 \%$ \\
\hline Average annual growth 1998-2001 & $0.3 \%^{\mathrm{a}}$ & $1.3 \%$ \\
\hline Urban population & & \\
\hline Million (2001) & 48 & 28 \\
\hline \% of total (2001) & $36 \%$ & $37 \%$ \\
\hline Average annual growth 1981-98 & $3.5 \%$ & $3.4 \%$ \\
\hline Average annual growth 1998-2001 & $3.5 \%$ & $7.0 \%$ \\
\hline
\end{tabular}

a In accordance with the World Bank's database (DDP) the total population of Pakistan was 141 million in 2001 and average annual growth during 1998-2001 was 2.4\%. However, in order to compare Punjab with the national averages on a consistent basis the Census Organization of Pakistan and Pakistan Federal Bureau of Statistics data were used for calculations in this table.

Source: Census Organization of Pakistan (1998) and Pakistan Federal Bureau of Statistics (2001).

7. Prior to 1998 the majority of the urban growth (74 percent) was generated by natural increase and only 15 percent was due to rural-urban migration (Hasan 2001). However, the recent jump in urban growth may indicate an increasing rural-urban migration or possibly increased reclassification of rural areas as urban. Furthermore, due to the way areas are classified as urban or rural, the actual level of both urbanization and its growth in Pakistan may be underestimated. ${ }^{1}$ For example, the expanding ribbon developments along major transport routes and peri-urban areas around cities are still classified as rural even though they have urban characteristics (World Bank 2004a).

8. Projections of urbanization indicate massive growth at both the national and provincial level. The Ministry of Planning's Vision 2030 estimates that Pakistan's total population will reach 218 million by 2030 and that 60 percent this of the total will be located in urban areas. In absolute terms, between 2001 and 2030, Pakistan's urban population will increase from 48 to 130 million persons - an average of 2.8 million person per year. In the case of the Punjab, urbanization trends and projections mirror nationwide patterns. Punjab's rate of urbanization is anticipated to increase from 37 to 60 percent between 2001 and 2030. In terms of absolute increase, between

\footnotetext{
${ }^{1}$ While official estimates indicate that 36 percent of Pakistan's population was urban in 2001, Hasan (2001) estimates it to exceed 40 percent.
} 
2001 and 2030 the Punjab's urban population is likely to increase from 28 million to 74 million, which translates into an average increase of 46 million people per year. ${ }^{2}$

9. Much of the urban population growth in the Punjab will be concentrated in the province's five major cities with populations above 1 million: Lahore, Faisalabad, Rawalpindi, Gujranwala and Multan (Census Organization of Pakistan 1998).

Table 2

Population Trends and Projections, 1981-2005 and 2030, (in '000s)

\begin{tabular}{|l|l|l|l|l|l|l|l|}
\hline & & & & & & & 2005-30 \\
\hline & & & & \%ACGR & \%ACGR & & Ann. Ave. \\
\hline City & $\mathbf{1 9 8 1}$ & $\mathbf{1 9 9 8}$ & $\mathbf{2 0 0 5}$ & $\mathbf{1 9 8 1 - 9 8}$ & $\mathbf{9 8 - 2 0 0 5}$ & $\mathbf{2 0 3 0} *$ & Increase \\
\hline Lahore & 2,953 & 5,144 & 6,131 & $3.3 \%$ & $2.5 \%$ & 14,737 & 344 \\
\hline Faisalabad & 1,104 & 2,009 & 2,347 & $3.6 \%$ & $2.2 \%$ & 5,641 & 132 \\
\hline Rawalpindi & 795 & 1,410 & 1,660 & $3.4 \%$ & $2.4 \%$ & 3,990 & 93 \\
\hline Multan & 732 & 1,197 & 1,418 & $2.9 \%$ & $2.4 \%$ & 3,408 & 80 \\
\hline Gujranwala & 601 & 1,226 & 1,442 & $4.3 \%$ & $2.3 \%$ & 3,466 & 81 \\
\hline Total of 5 & 6,185 & 10,986 & 12,998 & $3.4 \%$ & $2.4 \%$ & 31,243 & 730 \\
\hline Other Urban & 6,765 & 11,874 & 17,788 & $3.4 \%$ & $5.9 \%$ & 42,757 & 999 \\
\hline Punjab Total & $\mathbf{1 2 9 5 0}$ & $\mathbf{2 2 , 8 6 0}$ & $\mathbf{3 0 , 7 8 6}$ & $\mathbf{3 . 4 \%}$ & $\mathbf{4 . 3 \%}$ & $\mathbf{7 4 , 0 0 0}$ & $\mathbf{1 , 7 2 9}$ \\
\hline
\end{tabular}

* Based on the Provincial population growth rate of 3.57 percent per year

Source: Ministry of Planning Vision 2030

Government of Punjab Planning and Development Board.

10. Table 2 provides population counts for these cities for 1981, 1998 and 2005, as well as projections of populations to 2030, based on national and provincial trends. It illustrates the significant historical rates of urban population growth in the main cities and other urban areas of the province and provides estimates of projected population to 2030 based on Ministry of Planning projections. The total population of the Punjab's five largest cities will increase from 13 million in 2005 to 31 million by 2030, implying that the population will increase by 730,000 annually. Lahore will have the largest share of the increase, with 344,000 persons per year. This rapid urban growth poses unprecedented challenges for urban land and housing markets and the government's capacity to provide adequate infrastructure to support growth.

11. As the Punjab's economic development improves, the demand for housing, industrial, commercial and service facilities will also increase (Jiang et al 1998). This will place considerable pressure on land and real estate market as investors search for plant locations. In addition, as economic conditions improve, there should be an upturn in the demand for residential real estate from workers, expatriate Pakistanis and foreign nationals operating businesses in the province.

\footnotetext{
2 This estimate is based on the "step-down" method of sub-national population projection. It assumes that the Punjab's total population will remain at 57 percent of the nation, and that its urbanization rate will match the national level.
} 
12. The Punjab's high rates of urban growth combined with the restrictive environment for provision of land and housing have resulted in escalating land prices, which drive up the costs of infrastructure and urban development projects and they diminish housing affordability. In the long run rising land prices drive up labor and business costs, reducing a city's competitiveness (Dowall, 1998). It has also resulted in deteriorated and low quality infrastructure, large slum/squatter population and high household expenditures on housing.

13. Thus, the efficiency of urban land and housing markets can be expected to play an increasingly important factor in driving economic development. Attracting foreign direct investment, as well as accommodating domestic requires efficient and responsive land and real estate markets in Punjabi cities. How well are these markets working at present? The next two sections provide answers this question-what are the characteristics of well functioning and efficient urban land and housing markets, and what is the on-the-ground experience in Punjabi cities?

\section{Characteristics of Well-Functioning Urban Land and Housing Markets ${ }^{3}$}

14. Urban land and housing markets should efficiently allocate land and housing resources between suppliers and demanders. Housing supply should reasonably match the housing demands of households in terms of price, location and quality. For commercial and industrial real estate, businesses should be able to acquire or rent facilities, or purchase land for development without difficultly and at reasonable occupancy costs. For all classes of real estate there should be an inventory of land and properties on the market at any point in time so that buyers have alternatives, and sellers face competitive pressures from other sellers.

15. Effective real estate markets also are relatively transparent. Buyers and sellers can readily obtain information of the current prices of land, housing and other real estate being offered on the market at any time. Typically, real estate brokerage services operating within or across markets and provide information prices, supply and demand.

16. In most market economies, private production is the predominant mode of real estate development, for residential, commercial and industrial facilities. Furthermore in well functioning urban land markets, most land is privately owned-public land ownership is limited - usually to less than 5 percent of the market. ${ }^{4}$ Aside from a few exceptions, public provision of housing is miniscule relative to overall production, less than 5 percent. The full range of housing supply, including new as well as existing units should provide households with affordable options for purchase as well as rental. Well performing housing markets produce housing that is priced between 3 and 6 times total household income. For extremely low income households, shelter is typically provided through central and local government agencies, and non-profit, non governmental organizations. Depending on household incomes and housing

\footnotetext{
${ }^{3}$ This section draws on Elliot J Feldman; Michael A Goldberg. Land rites and wrongs: the management, regulation, and use of land in Canada and the United States. Boston OGH, 1988, and Dowall and Clarke, 1995.

${ }^{4}$ Hong Kong and Singapore are notable exceptions.
} 
prices, the private real estate markets typically produce housing that is affordable to households to the $30^{\text {th }}$ to $40^{\text {th }}$ percentile of the income distribution (Dowall, 1982). Households with lower incomes, typically rent accommodations, share housing with extended families or they postpone forming households. Some are fortunate to get housing assistance from government sources. The private production of residential real estate investment should comprise between 5-10 percent of GDP. The level of informal housing occupancy (houses built without approval, title or adequate urban infrastructure) should be less than 20 percent of the total housing stock (this is the average rate for middle income developing countries).

17. In the case of commercial and industrial properties, businesses should be able to acquire land and build facilities or rent space in existing buildings. Opportunities should be varied with buyers able to find locations that meet their requirements in terms of access to customers, ease of shipping inputs and outputs at affordable occupancy costs. Commercial and industrial real estate markets should have vacancy rates of 5-10 percent.

18. The purchase and transfer of land and property should be straightforward, requiring limited time (less than 30 days) and the total costs executing a transaction - sale, purchase, exchange should comprise less that 5 percent of the value of the property.

\section{The Punjab's Urban Land and Housing Markets are Not Performing Well}

19. Our review of key performance measures of urban land and housing markets - urban land supply, land prices, quality of the housing stock, access to urban services, construction costs, private sector participation in real estate development, and levels of informality in the housing production sector indicate that the Punjab's urban housing markets are not efficiently operating.

20. The total annual national investment in housing of Rs 150-160 billion (US\$ 2.3-2.8 billion) contributes less than one percent to the Pakistan's GDP, which is significantly below the level in developed and also in many developing countries. ${ }^{5}$ Also in terms of housing units constructed per 1,000 population Pakistan has among the lowest levels in the world -0.5 units versus the average of 6.7 for developed countries and 1.9 for post-soviet countries in 2000. As a result, the Government of Punjab estimates that the housing shortage in the province is 2.5 million units, ${ }^{6}$ while the total annual construction in the whole of Pakistan is only 300,000 units. (Ministry of Housing and Works, 2001.)

21. The majority of housing in Pakistan is constructed by individual land owners contracting small (and mostly informal) builders. However, the data on value added of the construction sector in Pakistan indicate that the government's share has been steadily increasing from 18 percent in 1999/2000 to 41 percent in 2002/03 (see Table 3).

\footnotetext{
${ }^{5}$ Housing construction composed $6 \%$ of GDP in Australia and Canada, $3.5 \%$ in UK and 4.5\% in USA in 2003 (Berger-Thomson and Ellis 2004), 5\% in Korea, 6\% in Brazil, 3\% in Russia and 1\% in India (FIAS 2005b). Data for Pakistan are from World Bank et al (2004a).

${ }^{6}$ www.punjab.gov.pk/hud/govt_servants_housing_scheme.htm and Dawn 2004.
} 
Table 3

Construction in Pakistan

\begin{tabular}{|c|c|c|c|c|c|}
\hline & 1999-00 & $2000-01$ & 2001-02 & 2002-03 & 2003-04 (P) \\
\hline $\begin{array}{l}\text { Construction, value added (\% of GFCF) } \\
\text { - of which by the private sector }\end{array}$ & $\begin{array}{l}2 \% \\
82 \%\end{array}$ & $\begin{array}{l}2 \% \\
84 \%\end{array}$ & $\begin{array}{l}2 \% \\
77 \%\end{array}$ & $\begin{array}{l}1 \% \\
59 \%\end{array}$ & $\begin{array}{l}1 \% \\
63 \%\end{array}$ \\
\hline $\begin{array}{l}\text { Construction of residential buildings } \\
\text { (\% of government's capital exp.) }\end{array}$ & $9 \%$ & $13 \%$ & $9 \%$ & N/A & N/A \\
\hline
\end{tabular}

NOTE: P - projected; GFCF - Gross Fixed Capital Formation.

Source: DDP.

22. While the number of builders appears to be large, majority of them is informal. Only about 270 of the 4,000 members of the Pakistan's Association of Builders and Developers are incorporated companies. In order to avoid taxation and scrutiny from the government departments communication and contracts between the builders and the consumers are also carried out mostly orally. (Aries Group et al, 2004.) However, such a system involves numerous risks for both parties and makes attracting formal financing difficult.

23. While some changes have started to take place in the building industry towards greater regularization of operations, those are at the very early stages. For example, some developers such as Eden Developers Limited, one of the larger builders in Lahore, have obtained credit ratings from Pakistan Credit Rating Agency in order to access financing (Aries Group et al, 2004). Yet access to formal financing is still very limited and available to the top builders and buyers in the highest deciles of income distribution. This translates into insufficient supply and high costs that only a small portion of the population is able to afford. Thus, the majority resorts to gradual and highly informal housing solutions.

\section{$\underline{\text { Urban land prices and construction costs are high }}$}

24. Property prices in the urban areas of Punjab, particularly, Lahore have been increasing rapidly during recent years. For example, in Lahore the ratio of the price of 1 kanal area $(0.125$ acres) to medium household income increased from 5 in 1998 to 40 in 2004 (Dowall 2004). At the same time as much as 80 percent of formally developed plots in Lahore remain vacant (World Bank 2004b). A recent survey of residential land prices indicates that raw land prices in newly developing areas of Lahore, Multan, Faisalabad and Rawalpindi range from Rs 100,000 to Rs. 240,000 per marla (25.3 square meters). This suggests 3 to 5 marla plots (targeted toward low and moderate income households) would fetch between Rs. 300,000 to 720,000 for a three marla plot and Rs 500,000 to Rs. 1,200,000 for a five marla plot. Pakistan's GDP per capita stands at Rs 132,000, meaning that a three marla plots costs between 2.3 and 5.5 times income and a five marla plot costs between 3.8 and 9 times income.

25. Residential construction costs are also high relative to income. Average quality construction costs range between Rs. 600-950 per square foot. A modest dwelling unit of 750 square feet would cost between Rs. 450,000 and Rs. 637,500. The ratio of housing cost (plot plus structure) to income (cost of the plot and the house) ranges between nearly 6 times income for a basic plot and house to 14 times income. These ratios are well above what is found in other countries with well functioning real estate markets (see above). 
26. As a result urban households spend a high portion of their incomes (34 percent in 2001/02) on housing and related services indicating the negative effects of unintended distortions of urban policies in Punjab (see Graph 2). Such levels are comparable with those in the US where households spend 32 percent on housing. Furthermore, due to the way the imputed rents are calculated by the Pakistan Federal Bureau of Statistics (see note for Graph 2). housing expenditures may actually be underestimated.

\section{Graph 2}

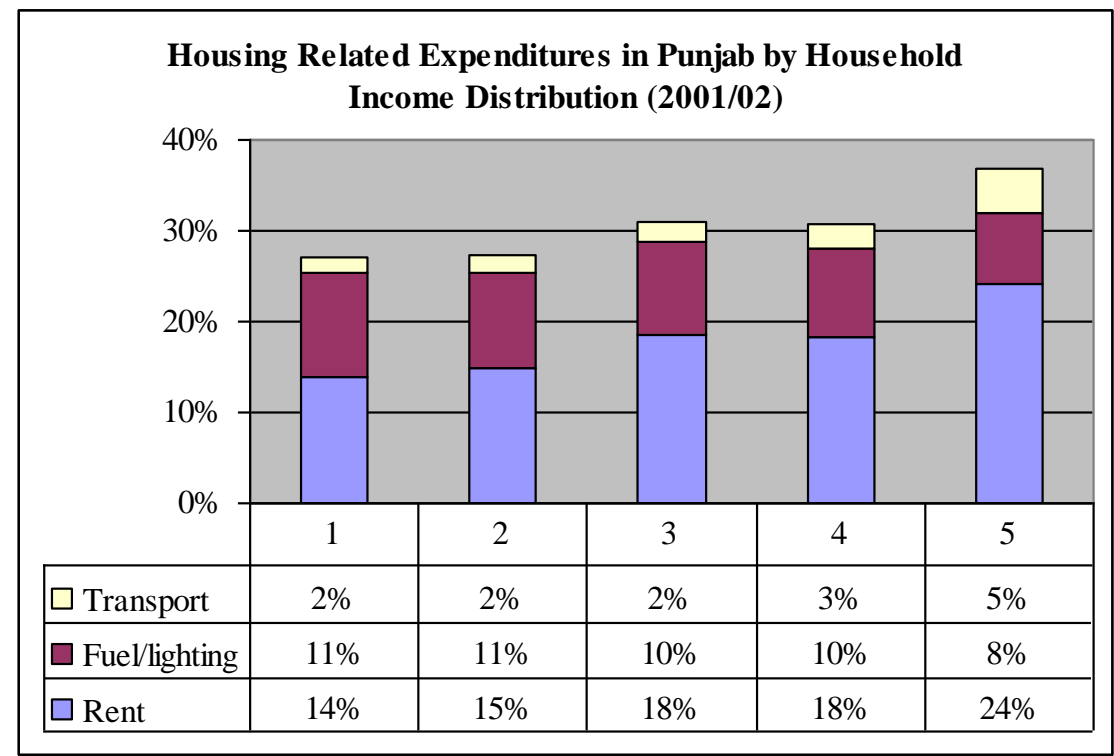

NOTE: imputed rent is estimated by applying an annual growth of 5.3\% since mid 1980s.

Source: Pakistan Federal Bureau of Statistics (2001/02).

27. Furthermore housing and housing related expenditures tend to rise at a faster pace than the general inflation mostly due to inflation in fuel, lighting, transportation and communication costs.

\section{Graph 3}

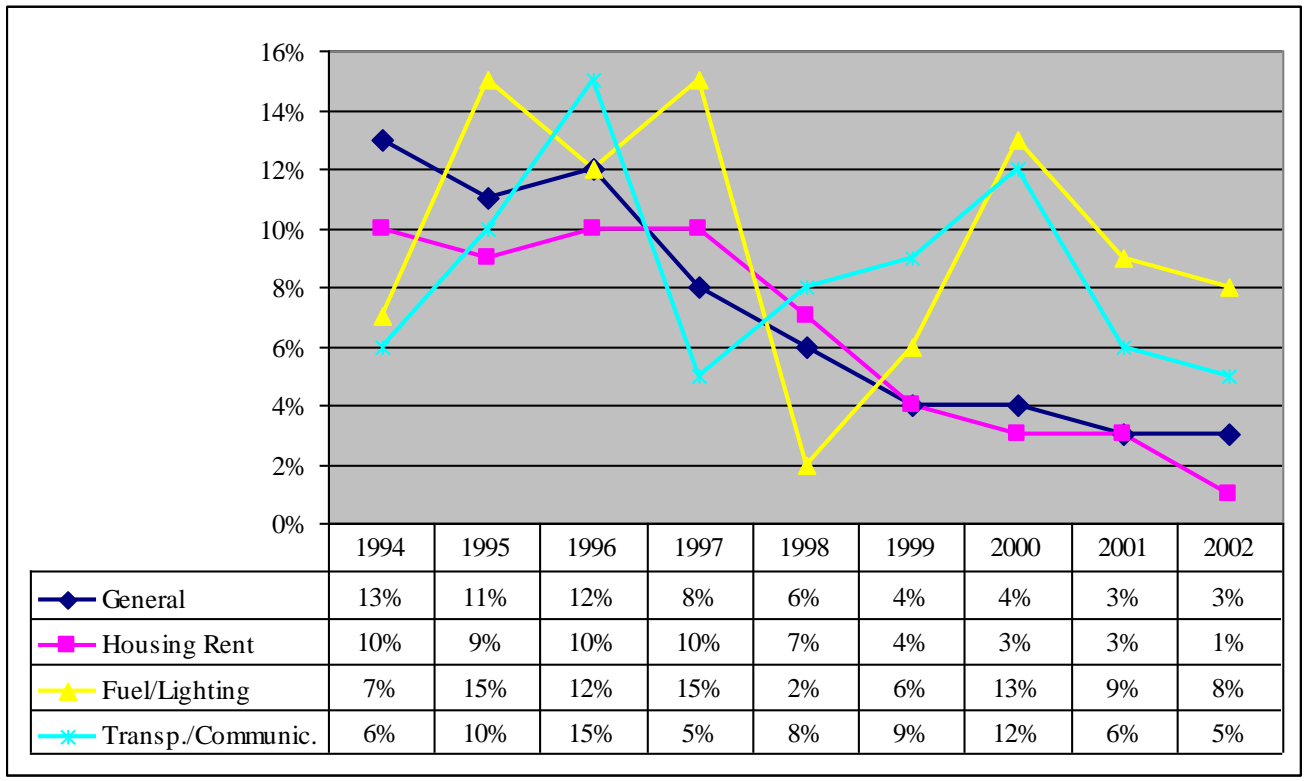


Source: calculated by author based on Pakistan Federal Bureau of Statistics (2004)

High land and housing prices have driven households into the informal sector

28. About 7.5 million people (35 percent of the Punjab's urban population) live in slums, with another 2.8 million (12 percent) living in katchi abadis (ADB 2003). However, this may be an underestimation due to definition of "katchi abadis" and it is likely that part of squatter population is not accounted for. ${ }^{7}$ Even with such a large slum settlements, household expenditures on housing are reaching the levels common in developed countries, although private construction industry is mostly informal and housing finance is essentially non-existent (less than 1 percent of GDP).

29. Formalization of slum and squatter settlements cannot be looked at in isolation from other reforms that are the actual causes of the informal housing, i.e. restrictive land and housing policies and regulations, distortive taxation, etc. Furthermore, formalization of slum and squatter settlements and the associated increase in property values may displace the poor tenants as oftentimes is the case with small scale formalization. However, when formalization is carried out on a broad scale, more poor landlords have the incentives to consolidate and expand, ensuring a more elastic supply of rental housing (Galal and Razzaz, 2001). Thus, achievement of desired benefits and more efficient housing and land markets require a comprehensive approach to the reforms.

30. A related issue is overcrowding. While data are not sufficient to fully assess the issue of overcrowding in Punjab, the average household size in the lower deciles of income distribution was almost double that in the higher deciles in 2001/02. This implies that overcrowding may, indeed, be an issue at least for the urban poor. Also, the number of housing units in Punjab increased at a lower pace ( 2 percent per annum) than the population growth during 1980-98, while the number of housing units in other provinces increased by 3 percent p.a., which was greater than the population growth of 2.6 percent p.a. (World Bank 2004a). However, incomes in the Punjab grew faster than those in other provinces during the same period. This suggests that the number of people per housing unit increased in Punjab, but decreased elsewhere, and indicates constraints in the province's housing market.

Table 4

Main Characteristics of the Housing Stock in Pakistan and Punjab (1998)

\begin{tabular}{|l|l|l|}
\hline & Pakistan & Punjab \\
\hline Total housing (units) & $19,211,738$ & $10,537,127$ \\
\hline Urban (units) & $6,031,430$ & $3,200,934$ \\
\hline Urban (\% of total) & $32 \%$ & $30 \%$ \\
\hline Persons per housing unit (average) & 6.8 & 6.9 \\
\hline Urban & 7.1 & 7.2 \\
\hline Persons per room (average) & 3.1 & 3.0 \\
\hline
\end{tabular}

Source: Census Organization of Pakistan (1998).

\footnotetext{
7 "Katchi abadis" was defined in 1985 as unauthorized settlement on state-owned land of more than 40 dwellings
} (ADB 2003). Thus, smaller squatter settlements and those on private lands would be excluded. 


\section{What's Causing the Poor Performance?}

31. There are a range of factors, each working independently and interdependently to stifle urban land and housing markets in the Punjab. The supply of serviced land is constrained by widespread public ownership of land, inadequate trunk infrastructure provision to developable sites, complicated property rights, land titling and registration systems, and inappropriate and inefficient land use plans and regulations, rent controls, highly and distorting taxes. These impediments make it difficult for land and housing markets to respond to housing demand and as a result land and housing prices are expensive. As a consequence, most households are priced out of the formal market and nearly 50 percent of housing is produced through informal procedures without infrastructure, titling and planning.

\section{$\underline{\text { High public land ownership }}$}

32. Public land ownership in Punjabi cities is very high. Since partition, government agencies have been granted large parcels of land, in large cities, where local development authorities are seen as the principal vehicle for residential development, large tracts of land have been transferred to these authorities. ${ }^{8}$ Unfortunately, the track record of Development Authorities to development residential projects is poor and much of their land is vacant. In Lahore 30 percent of land is owned by government, in other large cities it ranges from 20 to 40 percent. Much of this land is well located and if it were placed on the market, it could provide opportunities for residential, commercial and industrial development. Previous research on Karachi indicates that high rates of public land ownership stifle formal urban land market operations, and encourage the development of katchi abadis (Dowall, 1991b).

\section{$\underline{\text { Inadequate trunk infrastructure and services to residential areas }}$}

33. Another reason for constrained urban land supply is that most cities are not able to finance the construction of infrastructure to support development, and there are enormous backlogs. For example, Lahore needs to spend Rs. 55 billion (US \$ 0.9 billion) over the next five years to close its infrastructure gap. Unfortunately, Lahore's current annual public spending of Rs 1 billion is only a fraction of the need, which is estimated at Rs 11 billion p.a. (Dowall, 2004).

34. Private developers, including housing societies and cooperatives routinely face the problem of inadequate availability and/or significant delays in the provision of infrastructure such as roads, water, electricity, sewerage and gas by public authorities/agencies (Aries Group et al, 2004). ${ }^{9}$ This not only increases the costs to developers, but also financial risks of real estate projects and limits the availability of financing, particularly, from the formal private lenders. Thus, developers (as well as buyers) revert to savings and informal financing, which is broadly available, but very costly. Furthermore, regulations require the developers to pay a large portion

\footnotetext{
${ }^{8}$ Most of the land for housing purposes is developed by Pakistan Housing Authority, PHATA, Defense Housing Authorities, Cantonment Boards, city development authorities and trusts. The different authorities provide land with infrastructure such as electricity, water and gas, while housing is constructed by the buyers or land recipients.

${ }^{9}$ Aries Group et al (2004) and FIAS (2005b).
} 
of infrastructure costs up-front $\left(25-50\right.$ percent in Lahore $\left.{ }^{10}\right)$. These factors combined with the above discussed distortions and uncertainty in regards of property rights translates into high property prices that are affordable only to a small portion of the high income population and businesses.

35. Public agencies plan their infrastructure investments based on city master plans, and program investments according to plans and not economic reality (i.e. "actual demand"). Furthermore, most infrastructure investments are made and services are provided by central or provincial government agencies, including Development Authorities. There is little role for or coordination with the local governments. Furthermore, due to highly subsidized services and limited financial capacity of local governments as discussed above the available funding for any investments is very limited and insufficient to meet ever increasing demand. Majority of local government budgets (60 - 70 percent) are spent on recurrent expenditures, while annual development expenditures in 54 percent of TMAs are below Rs 60 (US\$ 1) per capita.

36. As a result, businesses and developers face major difficulties in getting connections to utilities, particularly, gas and electricity, which typically delays large-scale construction projects by about 12 months and entails significant amounts in bribes (FIAS, 2005b). The consequences of inadequate infrastructure provision are staggering--only 58 percent of the urban housing units in Punjab had connection to the piped drinking water in 1998. versus 76 percent of the province's general population and 65 percent average in Pakistan. Furthermore, there are great disparities among the districts and TMAs in Punjab - connections to piped water and drainage/sewerage coverage varied from 7 to 100 percent and from 29 to 100 percent respectively. (see The level of metering of utility consumption is also very low. Even in Lahore only 30 percent of water connections are metered (LDA 2004).

\section{Graph 4}

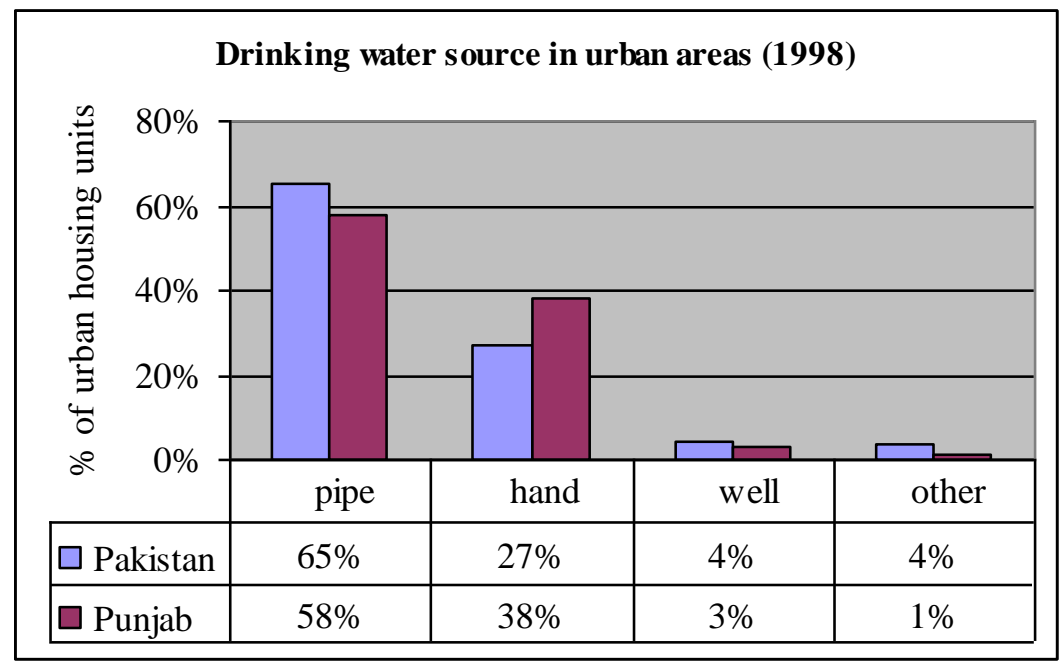

Source: Census Organization of Pakistan (1998).

\footnotetext{
${ }^{10}$ Lahore Policy for Payment of Cost of Trunk Infrastructure in Advance for Approval of Private Housing Schemes

- http://www.lda.gop.pk/lda_cmp.html.
} 
37. Water and sewerage services in Punjab are not reliable, nor are they sustainable. In major urban centers of Pakistan a typical daily service of water supply is $9-10$ hours and service coverage is 32 percent (Ministry of Water and Power of Pakistan, 2002). At the same time waste water, including from industrial consumers, is disposed of without treatment creating an increased risk to environmental and water pollution. ${ }^{11}$

38. Low cost recovery exacerbates the situation further. Due to the segregated and unclear institutional and organization framework for service provision, investments are carried out in a piecemeal fashion rather than large scale or TMA-wide investments in trunk infrastructure and expansion of services.

39. The Ministry of Water and Power of Pakistan (2002) has recognized the worrying situation in the quality of water in Punjab and the whole country. Drinking water in major urban centres of the Punjab seldom meets WHO Guidelines. Water samples from Lahore, Rawalpindi and Islamabad have been determined to be unfit for human consumption due to fecal contamination. High concentrations of nitrates have also been detected in drinking waters in Rawalpindi as well as Islamabad and other cities. Nitrate leaching from heavy fertilizer use is also an issue in southern Punjab. Many areas near Lahore have water with very high fluoride content resulting in different ailments of the consumers.

40. Most businesses use their own water sources as municipal water supply to industries is estimated at 2 percent of the annual consumption by the manufacturers of the major products (29 million $\mathrm{m}^{3}$ versus 1.5 billion $\mathrm{m}^{3}$ ). The industrial demand is expected to increase even further and reach 1.8 billion $\mathrm{m}^{3}$ by 2011 and 2.3 billion $\mathrm{m}^{3}$ by 2025. (Ministry of Water and Power of Pakistan, 2002)

41. Similar situation is observed in solid waste management. In Lahore solid waste collection is estimated by LDA (2004) to be about 70 percent. There are no sanitary landfills in Punjab and the dumping grounds are not entirely legal. (World Bank, 2004a).

Weak property rights and ineffective land titling and registration systems

42. Another constraint of land supply is caused by inefficient mechanisms for registering property transactions. While registration of property in Pakistan appears to be rather efficient and comparable to other countries ${ }^{12}$, it does not guarantee effective title and enforcement of property rights. Incentives for property registration in Pakistan are very weak and procedures have numerous loopholes as documented in World Bank et al (2004a) and Aries Group et al (2004). For example, Pakistan law does not envisage the provision of title certificate by the government. The records rather indicate the person responsible for paying property related taxes who is therein presumed to be the owner. However, such ownership documents have been questioned in numerous court cases. The law also allows for optional registration of land or change of ownership is also in some cases. For instance, under Islamic Law oral declarations of gift do not

\footnotetext{
${ }^{11}$ World Bank (2004a) and Ministry of Water and Power of Pakistan (2002).

${ }^{12}$ In accordance with Doing Business database it requires 4-5 procedures and 49 days to register a property in Pakistan costing equivalent of 4.2 percent of the property value versus 4 procedures, 34 days and 4.8 percent average in OECD countries (http://www.doingbusiness.org/Default.aspx).
} 
have to be registered. Thus, the system of law allows for legally valid titles to be created without recorded transactions.

43. The situation is further complicated by benami (documented, but unrecorded) transactions. ${ }^{13}$ Benami transactions are legally protected in Pakistan under Benami Act and allow the parties to circumvent taxation and restrictions on maximum area of landholding. The elimination of benami transactions has been recommended among other things by the Word Bank and the International Monetary Fund (World Bank et al, 2004).

44. Recent studies in Pakistan ${ }^{14}$ indicate a number of other issues impeding the development of effective and reliable property records such as institutional fragmentation among the numerous record keeping entities, inconsistencies in record-keeping methodologies, rules and procedures among and within jurisdictions, lack of security checks and difficult reconstitution of chains of titles. There are a number of different agencies keeping records related to property rights, including Land Registrar, Revenue and Excise Departments as well as local Development Authority, Municipal Corporations, Cantonment Boards and other. (World Bank, 2005b). Furthermore, most records are kept manually.

45. The above situation leads to property records being highly incomplete and unreliable. It is estimated that there are over a million land-related disputes pending court resolution in Pakistan composing 40 percent of all court disputes (FIAS, 2005b). Thus, court proceedings take years to resolve.

46. Experience in many countries also shows that establishment of clear property titles has great potential benefits. Residential plots with clear titles in Jakarta sold at a 45 percent premium over comparable plots without a clear title ${ }^{15}$. The risk of eviction lowered the value of housing units in Manila by 25 percent. ${ }^{16}$ Titling resulted in property value increases in Davao (the Philippines) and barrios of Quito (Equador) by 58 percent and 21 percent respectively. ${ }^{17}$ Such benefits are, of course, highly dependant on specific characteristics of the housing and land market such as actual threats of eviction in informal settlements, availability of credit and level of distortion of related prices, e.g. rent controls, subsidies and differentiated taxation based on the land use (agriculture / commercial / residential / rental, etc.).

47. Indeed, a recent survey of more than 700 firms throughout Pakistan ${ }^{18}$ revealed that land market issues are the most important barrier to investment in Pakistan. 79 percent of respondents identified land acquisition and site development regulations as a barrier and 54 percent of them considered it to be severe. Land acquisition on average required 140 days and 20 different documents in the case of government land and 64 days and 10 documents in the case of private land. Furthermore, 53-55 percent of the respondents reported paying bribes to expedite the process for acquisition of land or leasehold rights.

\footnotetext{
${ }^{13}$ World Bank (2002b), World Bank et al (2004) and Mahmood (2004).

${ }^{14}$ Aries Group et al (2004) and FIAS (2005b).

${ }^{15}$ Dowall and Leaf (1991) as cited in Dowall and Clark (1996).

${ }^{16}$ Friedman, Jimenez and Mayo (1988) as cited in Dowall and Clarke (1996).

${ }^{17}$ Jimenez (1984 and 1988) and Simon (1995) respectively as cited in Galal and Razzaz (2001).

${ }^{18}$ Administrative and Regulatory Costs Survey carried out as a part of the Review of Administrative Barriers to investment in Pakistan in 2005 (for a full report see FIAS 2005a).
} 
48. Finally, unclear property rights in Pakistan have resulted in mortgage finance being limited only to the larger urban areas and upper income groups. The unclear property rights in combination with other restrictive policies discussed in this section also stifle the supply of housing and land, which is particularly important in an environment of a rapid urban expansion.

Counterproductive urban planning and development regulations

49. Urban planning practices and associated regulations also limit the supply of urban land. Planners seem more interested in controlling urban growth than in framing plans and strategies to accommodate growth and promote economic development (World Bank, 2004a). An example of this is the recently completed Integrated Master Plan for Lahore (IMPL). A review of the plan by the World Bank (2004b) revealed that, while IMPL is very comprehensive, it does not have a strong strategic orientation or clear vision for the future development of the city based on a consensus among the stakeholders. Furthermore, the plan is based on rather basic assumptions and supply driven projections for the need of land, which is very likely to result in misallocation of land among the different uses. However, the need and demand for housing and land are rather different concepts. While the need for housing is determined by the number of households, the actual demand is determined by the incomes.

50. Contrary to the intention, the proposed zoning and subdivision regulations are more likely to reinforce the current trend of low-density ribbon development and land subdivision regulations could exacerbate the slow pace of construction in Lahore. These issues are particularly important considering the difficult procedures for the commercialization of residential property and rapid urbanization, and are likely to impede the formation and growth of small businesses (World Bank, 2004b).

51. In terms of urban land regulations the highly restrictive floor area ratios (FARs) appear to be the main constraint limiting the density of urban development. In Lahore FAR is set uniformly low at 1:1.5. However, in some areas (for multi-storey buildings and along major routes) the ratio is set at 1:4 (World Bank, 2004b). In contrast, FARs in center business districts (CBDs) of most large cities in other countries are set at much higher levels of 5 - 15 (Bertaud 2002).

52. These restrictive FARs are producing striking anomalies. An analysis of Lahore indicates that its density has a "U" shape. It indicates high density in the city center and periphery implying significant inefficiencies for businesses, transport and infrastructure development. In contrast, density profiles in cities of most developed as well as developing countries is exponentially negatively sloped indicating decreasing density with increase in a distance from CBD_for example Los Angeles, New York, Paris, Barcelona, Beijing, Bangkok and other) (Bertaud 2004).

53. An FAR set significantly below the level of its market equilibrium has a number of negative consequences and imposes large costs on the city's economy. It increases the demand for land across the city as more land is required for the same amount of floor space. (World Bank, 2004b.) A paper by Ohls, Weisberg and White (1974) showed that zoning regulations restricting the supply of land available for development below the level that would be normally exchanged 
in the market increase land prices. A model developed by Lin, Mai and Wang (2003) demonstrates how a uniform restriction on the FAR encourages non-productive use of housing capital, raises equilibrium housing prices and lowers city growth. In contrast, an increasing FAR towards the city center increases the productive use of housing capital and reduces housing prices, thus, fostering the city's economic growth. Low FARs also cause greater dispersion of economic activity and housing reducing the benefits of agglomeration effects ${ }^{19}$ and requiring lengthier trips. This finding is supported by Bertaud and Brueckner (2003) who estimated that the costs associated with low FARs in Bangalore (India) may be as high as $3-6$ percent of household wealth.

54. Furthermore, low FARs limit the quantity of available formal housing within the city's boundaries. This results in greater population densities in any given location within the city as well as contributes to escalating land and housing prices as already experienced in Lahore. As a result, the poor and lower income households are priced out of the market. In less restricted real estate markets private developers are able to adjust to the increasing demographic and economic pressures and rising land and construction prices. For example, Dowall (1992) documents that developers in Bangkok increased the density of housing projects during 1974-1988, the period of rapid urban growth and increasing land and housing construction prices. The average number of units per hectare increased from 35 to 56 and multi-family housing increased from less than 2 percent of the new construction in 1986 to 43 percent in 1990. Such shifts in developer operations made housing more affordable. As a result private sector low cost housing was priced below many housing units provided by the National Housing Authority (Dowall, 1992). Furthermore, during 1986-1990 almost half of the increase in the housing stock was produced by private developers, while informally produced housing in Bangkok composed mere 3 percent of the total. In contrast, informally produced housing in cities with highly constrained land markets composed 20-80 percent of the total. ${ }^{20}$

55. The experience in Seoul in 1970s and 1980s, on the other hand, demonstrated how highly restrictive land regulations contributed to rapidly increasing residential prices under similar growth pressures. Such regulations included zoning controls for land use, restrictions on conversion of agricultural land and greenbelt policy that reduced the developable land in the Seoul metropolitan area by 50 percent. (Dowall and Clark, 1996 and Dowall, 1998.) The research indicates that such growth binding regulations are particularly regressive in welfare terms (Cheshire and Sheppard, 2002a). Site planning and subdivision controls reduced the area of land available for residential construction in Seoul by another 40 percent. At the same time the low FARs of 1.25 to 1.0 restricted the possibility to compensate the shortage of land with the height of buildings. All these factors contributed to the exorbitant 24 percent annual increase in land prices during 1974-1989. (Dowall and Clark, 1996 and Dowall, 1998.)

56. Low FARs have other negative effects such as lower incentives to invest in development and redevelopment of available land as discussed by Bertaud and Brueckner (2003) and reduced

\footnotetext{
${ }^{19}$ For discussion on agglomeration effects see work by Glen Ellison and Edward L. Glaeser, Donald R. Davis and David E. Weinstein, Sukko Kim, Stuart S. Rosenthal and William C. Strange, Michael J. Orlando, Ryohei Nakamura, Courtney LaFountain and others.

${ }^{20}$ Specifically, informally produced housing was 60 percent in Karachi during 1981-1988, 77 percent in Jakarta during 1980-1988, and 80 percent in Addis Ababa during 1984-1995 (Dowall 1998).
} 
residential mobility. Restricted mobility affects those in the lower deciles of income distribution the most as their access to jobs is reduced due to increased transportation time and costs. If the minimum land consumption is not limited or is set sufficiently low, the low-income households could afford to locate anywhere in the city. However, when regulations impose low density the minimum amount of land required for a unit of floor space is usually above the affordability level of the poor. Thus, they are forced to locate further away from CBD and, consequently, from the job markets. As a result, the combination of such restrictions with the increasing costs of land and urbanization cause segregation of the poor. A greater number of people are forced to choose illegal housing and business space arrangements and sacrifice the level of living and work conditions. The above restrictions have even further negative effects on the environment due to greater pollution and need to convert more agricultural land to urban use to accommodate the artificially created excessive need for urban land. ${ }^{21}$

57. The magnitude of the above phenomena indicates that there are some important structural and regulatory constraints that affect housing and land markets in Punjab. To understand the underlying factors and possible causes of the above phenomena the paper reviews the available information in the key areas related to urban housing and land markets in the province - socioeconomic context, regulatory framework, urban planning, provision of infrastructure and government programs and subsidies. Thereafter, the effects of this environment on the housing and land markets are discussed.

58. For example, Malpezzi and Ball (1991) showed that there is a positive correlation between the general distortions in a country's economy and house price to income ratios in developing countries, i.e. the larger the distortions, the higher the house price to income ratios. Empirical evidence also demonstrates that land markets are rather efficient in capitalizing the impacts of regulation, local public goods, amenities and tax policy, i.e. any discounts (premiums) for restrictive (beneficial) policies and regulations are to a great extent included in the market prices of land. ${ }^{22}$

59. Dowall (1995) provides an extensive overview of the effects of government housing and land policies on the property prices in different countries. For example, in UK before regulations began to constrain land supply in the late 1940s there was no apparent trend in real land prices for housing (they even seemed to be falling rather than rising) despite the increase in the number of households and real incomes. However, during 1955-2002, when the effects of regulations on the new construction started to become more apparent, the real price of residential land increased by a factor of 11 . In contrast, the real house prices increased by only 3.4 times over the same period (Cheshire and Sheppard 2004).

60. In Malaysia the annual costs of inappropriate land-use and housing development regulations were estimated to amount to 3 percent of GDP in the 1980s (World Bank 1989a). In Seoul (South Korea) site planning regulations, subdivision controls (i.e. setbacks, plot and street widths and lengths, etc.), floor area ratio (FAR) limits and building codes resulted in a built-up area to land ratio of 0.56 in late 1980s (Dowall and Clark 1996). In an environment of rapid

\footnotetext{
${ }^{21}$ For discussion on these effects see work by Alain Bertaud - http://alain-bertaud.com/

${ }^{22}$ Foe more detail see Thorsnes (2000), Hilber and Mayer (2001), Ihlanfeldt and Shayghnessy (2004), Cheshire and Sheppard (1995, 2002b), Gibbons (2002), and Cheshire and Sheppard (2004).
} 
growth such restrictions fueled land price escalation averaging 24 percent p.a. in Seoul during 1974-1989 (Kim 1991). Contrary to Seoul, more liberal land and building regulations in Bangkok (Thailand) and Bogota (Colombia) allowed developers adjust construction densities under increasing demand and cost pressures (Dowall and Clark 1996).

61. In an environment where developers and households can not adjust construction densities, i.e. increase built-up area relative to the underlying land plot, more people resort to informal solutions. For example, in Karachi in 1988, the average price of a house in a planned housing estate was equivalent to 8 times the average annual income of low income households. Thus, families resorted to informal housing in katchi abadis at a quarter of the cost of planned housing (Dowall 1991a).

62. While government interventions such as land regulations, property rights, taxation and infrastructure investments are necessary, they can become serious obstacles to development of cities when designed poorly. In choosing the level of regulatory intensity the government implicitly determines the characteristics of the consumers it wishes to attract (Thorsnes 2000.) The critical issues are ensuring balance between the government control and market discretion and the benefits of regulations and the costs of compliance.

$\underline{\text { Subdivision and construction standards }}$

63. Established minimum construction standards affect affordability and implicitly establish the "minimum income" for formal housing and land owners / residents as well. For example, in Jakarta (Indonesia) the minimum land plot size, planned population densities (similar to FARs) and restrictive zoning that had little relationship with the market trends were estimated to make land affordable to only 5 percent of the urban population (Bertaud 1989).

64. There has been no recent study of the housing standards in Pakistan or Punjab. However, one of the main conclusions of the World Bank's Shelter Sector Review in Pakistan in 1989 was that the housing standards at the time had resulted in over-designed and, hence, unaffordable housing. The current guidelines for private housing schemes issued by the LDA and Punjab Housing and Physical Planning Department stipulate requirements for land distribution that are also likely to result in over-designed and expensive housing projects. For example, all private housing schemes are required to have a minimum size of 160 kanals ( 20 acres), 20 percent of which is to be pledged with the authority as a guarantee of completion of the scheme (FIAS, 2005b). In addition, subdivision regulations require that approximately 50 percent of the gross land area of the project be set aside for public uses - circulation, public facilities, parks, etc. A more common and reasonable ratio would be about 30 percent. The maximum ceiling for commercial land is set at a mere 2 percent. ${ }^{23}$ Similarly, only 2-3 percent of land in a typical government land development scheme is allocated for commercial properties. Overall these requirements create perverse incentives for private developers and make it very difficult for them to produce affordable housing (for example that can only sell 50 percent of the land that they have acquired).

\footnotetext{
${ }^{23}$ Punjab Guidelines / rules and regulations for processing and approval of private housing schemes (http://www.lda.gop.pk/lda_cmp.html).
} 
65. The large minimum size of a housing project forces new residential developments further and further away from a city center as land plots available for construction tend to be smaller towards the center of a city. Furthermore, large project sizes exclude smaller developers from the formal market, thus, reducing competition, particularly, in the lower-end market. The 2 percent limit for commercial property also limits the availability of new space for businesses. As a result, it is not surprising that the economic development and increasing demand for commercial land translates into skyrocketing prices due to highly inelastic supply. In addition, most poor live in the areas of their employment due to the fact that they can not afford the costs of daily transportation. Thus, segregation of residential and commercial areas and allocation of such a small portion of land for commercial purposes work contrary to pro-poor policies and force people to resort to informal arrangements either for housing or for employment.

\section{Limited Formal Property Finance}

66. Another impediment to affordable housing production is that housing finance is very limited in Pakistan, compared to other developing countries in the region and around the world. The outstanding housing loans amounted to US\$ 0.4 billion or 0.6 percent of GDP as of December 31, 2003, which is among the lowest levels in the world. (Aries Group et al, 2004 and World Bank, 2002a.) Even at its peak the annual flow of loans from formal financial institutions reached only 1.5 percent of the total housing investment as compared to 25 percent in South East Asia and 50 percent in the United States. (D'Souza, 2003.)

Table 5.

Outstanding Housing Loans as of December 31, 2003, for Pakistan

\begin{tabular}{|l|l|l|}
\hline & Rs million & US\$ million \\
\hline Construction & 17,336 & 288.9 \\
\hline Purchase & 4,482 & 74.7 \\
\hline Renovation & 883 & 14.7 \\
\hline Total & $\mathbf{2 2 , 7 0 0}$ & $\mathbf{3 7 8 . 3}$ \\
\hline
\end{tabular}

Sources: Aries Group et al (2004).

67. The major lender for housing in Pakistan is the House Building Finance Corporation (HBFC) - a non-banking institution that accounted for 80 percent of the total formal housing loans (Rs 30 billion / US\$ 0.5 billion) in 2004. However, recently the banking institutions have been increasing their lending for housing and Citibank and ABN AMRO Bank were the biggest loan originators in terms of annual flows (about Rs 1 billion / US\$ 17 million a year each) (Aries Group et al, 2004).

68. The main reason for the limited availability of housing finance is the weak enforcement of lenders' rights (mortgage / property rights) and foreclosure laws. ${ }^{24}$ Funding does not appear to be an immediate issue due to the recently increased liquidity of the financial sector. (World Bank, 2003b.) However, access to long term resources by mortgage lenders is necessary for the longer term development of mortgage lending.

\footnotetext{
${ }^{24}$ For more details see World Bank et al (2004) and Aries Group et al (2003).
} 
69. In order to address this situation the Government has undertaken a number of steps as outlined in FIAS (2005b) and Aries Group et al (2004). The State Bank of Pakistan appointed an advisory group comprising housing and finance experts to advise the government on measures that would promote the development of housing and housing finance markets. The Financial Institutions (Recovery of Finances) Ordinance of 2001 streamlined the foreclosure process by allowing financial institutions to repossess property without court decision. However, this procedure is currently undergoing an ultimate test as two recent cases have been taken to the superior court. Furthermore, it may take some time for the lenders and borrowers to accept the new procedure as a general industry practice.

70. The credit regime for housing finance was also recently liberalized by raising the limits for the bank exposure to the housing sector from 5 to 10 percent of their portfolios, increasing the maximum loan to value ratio to 80 percent, increasing loan limits to Rs 5 million (US\$ 83,333) for individuals and Rs 7.5 million (US\$ 125,000) for groups and extending the maximum loan term from 15 to 20 years.

71. The combination of a recent stabilization in the country's economy, the government steps towards liberalization of the financial markets and the strengthening of lenders' rights are gradually changing the environment for lending. The results are falling interest rates and increasing affordability of housing loans. For instance, interest rates on housing loans fell from 14 percent in 2002 to about 10 percent at the end of 2003 (World Bank, 2003b), although they have been rising again during 2005 (FIAS, 2005b). However, broad access to formal financial markets to the majority of the population will require addressing the underlying sector constraints such as strengthening of property rights and streamlining housing and land market operations.

\section{$\underline{\text { Rent Control }}$}

72. Rent control thwarts the construction of new rental apartments and stifles the maintenance of existing units. The current rent control legislation (Punjab Urban Rent Restriction Ordinance of 1959) provides extensive tenant protection for residential and non-residential property and land, which combined with higher taxation rates for rental units discourage investment in rental property.

73. The law in general provides for no rent increase for a 3 year period. In the case of land and residential premises rent can be increased during the 3 year period only, if some addition, improvement or alteration to the property has been made by the landlord at the request of the tenant. For non-residential premises the law allows for an automatic increase in rent by 25 percent every 3 years. As inflation has dropped below 10 percent in Pakistan since 1997, such an increase compensates for at least a general increase in prices although it does not take into consideration the trends in property market. However, throughout most of the 1990s, three year inflation was much higher - 29-38 percent.

74. In the case of tax increases, the landlord may charge the tenant only half of such increase and only upon the approval by the Controller. The Controller is a judicial officer appointed by the Provincial Government who has a sole authority to determine the fair rent for land and 
residential premises, fairness of eviction, building maintenance, conversion of residential building into non-residential, etc. ${ }^{25}$

75. Eviction is possible in the case of non-payment within 15 days in the case of written contract and 60 days in the case of no written contract. However, in the case of new construction or major renovation the previous tenants have the first right to a rental space of up to the same size in the new building at a fair rent as determined by the Controller. ${ }^{26}$

76. While rent control legislation exists in many developed as well as developing countries ${ }^{27}$ and has been studied rather extensively, it still remains a controversial issue. Studies in Cairo (Egypt), Kumasi (Ghana) and Mexico City (Mexico) revealed that effective rent controls had, indeed, helped the tenants who had stayed in the same property over time (Malpezzi and Ball, 1991). In Chile rent controls had lead to a sale of rental houses and apartments to tenants at attractive prices (UN-HABITAT 1989).

77. However, there appears to be a much greater evidence of the negative effects of the rent control on housing quantity and quality and residential mobility, particularly, in the long term.

78. Reduced housing quantity and quality. The negative effects of rent controls on the investment in rental housing and shifting property to other uses (i.e. commercial / office / owner occupied) have been extensively documented. ${ }^{28}$ For example, rental housing in Cambridge and Brookline (Massachusetts, USA) in 1980s and Berkeley and Santa Monica (California, USA) during 19781990 decreased by $8-14$ percent after the introduction of stringent rent controls. At the same time rental housing in most nearby locations rose during the same periods of time. In UK, where rent control was introduced in 1947, the share of private rental units dropped from 53 percent in 1950 to less than 8 percent in 1986. (NMHC, 1996)

79. Furthermore, it has been found that tenants receive only part of the benefits of the rent control as landlords tend to reduce investment in the property's maintenance. A study by the Rand Corporation of Los Angeles' rent control law ${ }^{29}$ found that 63 percent of the benefit of lower rents were offset by losses due to the deterioration of the housing unit. A study in New York (Pollakowski, 1999) found that regulated housing had much higher incidence of deficiencies than unregulated housing despite significant tax benefits provided to rent controlled landlords.

80. Based on such findings, it is not surprising that the urban rental market in Punjab is rather small and composes an estimated 20 percent of the total. In contrast, rental housing in Islamabad with less restrictive tenant laws composes 40 percent, which is more in line with that in OECD countries. $^{30}$

\footnotetext{
${ }^{25}$ Punjab Urban Rent Restriction Ordinance (1959) and World Bank et al (2004).

${ }^{26}$ Punjab Urban Rent Restriction Ordinance (1959) and World Bank et al (2004).

${ }^{27}$ USA (California, District of Columbia, Maryland, New Jersey and New York).

${ }^{28}$ See UN-HABITAT (1989), MacLennan (1986), Rakodi (1989), Benton (1987) and Pollakowski (1999 and 2003).

${ }^{29}$ Cited in NMHC (1996).

${ }^{30}$ The average for OECD countries is 38 percent (The Economist, 30 March 2002). Data for Pakistan are from FIAS (2005b).
} 
81. Besides discouraging the supply of rental units such restrictive legislation contributes to a decrease in overall housing supply as it discourages redevelopment and renovation. Buildings, which are under rent control, can not be redeveloped or even renovated until the tenants move voluntarily out of the building. Thus, oftentimes city development bypasses the areas under rent control, which essentially become a form of "frozen" land (Bertaud 2002). In the extreme case of Mexico City the rent controls in late 1980s resulted in land plots that had rent controlled property being valued less than a vacant plot and the only way to evict tenants was to collapse the building (UN-HABITAT 1989).

82. Rent control to a greater or lesser extent is usually imposed as a blanket measure, which is also the case in Punjab. Therefore, the benefits are distributed to the general population rather than targeted to the poor and vulnerable. Thus, there is a significant leakage of benefits to the higher income residents. Although rent control is intended to help the poor, oftentimes it does not as most of the poor in developing countries live in informal settlements that are not covered under the rent control and/or are not familiar with the rent control legislation. ${ }^{31}$

83. A household survey in Pune (India) in 2002 revealed that 35 - 40 percent of rent control benefits occurred to the households in the top 40 percent of income distribution (Hammam and Lall, 2005). In New York City as much as 70 percent of the rent control benefits went to tenants residing in affluent neighborhoods and rent-controlled households with incomes greater than US\$ 75,000 received nearly twice the average subsidy of households with incomes below US\$ 10,000 (Pollakowski 1997). Similarly, residents of rent-controlled housing in Cambridge, Massachusetts, had higher incomes on average than other residents of the city, including homeowners (NMHC 1996).

84. The poor as well as young households oftentimes face additional barriers to rent controlled housing through high entry costs. Rent control tends to foster the development of illegal rental market, "insider market" (i.e. rental units are passed among friends or family members) and emergence of alternative forms of payments such as key money, advance payments and finder's fees. Such phenomena are observed not only in developing, but also developed countries. (NMHC 1996.) Thus, the rent control policy may actually result in hurting those that it intends to protect most.

85. Due to the fact that rent control benefits are tied to the property rather than the individual, households tend to stay in the same property for long periods of time even when the location of jobs or other factors in the household situation change. For example, Pollakowski (1999) found that rent control in New York City more than doubled the expected duration of residence. This not only reduces the mobility of the labor markets, but also increases traffic congestion as families are willing to make longer trips to their places of work to keep the rental benefits.

86. Reforming rent control may require a gradual process as abrupt elimination may result in immediate shock that would hurt those in the lower deciles of income distribution most and may prove difficult to implement from the perspective of political economy. Furthermore, oftentimes, including the case in Punjab, rent control is only one of the several and not the most important

\footnotetext{
${ }^{31}$ A study in Bogota (Columbia) found that only $17 \%$ of tenants in illegal settlements had a written contract and only $25 \%$ of landlords and $20 \%$ of tenants understood the rental legislation (UN-HABITAT, 1989).
} 
factors causing shortages of developed land and discouraging investment in housing. ${ }^{32}$ Nevertheless there are significant gains to be obtained through deregulation. For example, Pollakowski (2003) estimated that 8 - 29 percent of investment in formerly rent controlled buildings in Cambridge (Massachusetts, USA) was due to elimination of rent control in 1994.

\section{Distortive Taxation}

87. Property taxes are important revenue sources for local governments in most developed and many developing countries. However, in Punjab the median share of property taxes in the total revenues of the five largest cities (Gujranwala, Multan, Lahore, Rawalpindi and Faisalabad) was 4 percent in 2002/03, which is significantly below the 17 percent median for the large cities in other developing countries. Low levels of property tax revenues mostly stem from significant tax exemptions, the linkage of property taxes to the property's rental rather than market value and poor collection. A World Bank (2004b) assessment indicates that the exemption of properties of less than 5 marla (1,300 sq.ft.) in katchi abadis, or in the lowest three levels of the property tax schedule (Zones D-G), is estimated to reduce property tax revenues by as much as 25 percent in Lahore.

88. Due to the stringent rent control legislation the rental value of property is also much lower than its market-based rental value would be, resulting in lower property taxes. The capital value is one instrument which is by and large, though not $100 \%$, neutral from the rent control. Preliminary analysis (World Bank 2004b) of the assessment system used in Lahore and other cities indicates that four to five fold increases in property tax revenue is possible by de-linking property taxes from rental values. In addition, collection efficiency also appears to be low in Punjab, as Lahore collected about half of the amount due to it in the form of property tax.

89. Given the limited revenue generating capacity of the property taxes, it is not surprising that stamp duties have become the main revenue source for local governments. In the five largest cities of Punjab the majority of tax revenues (87 percent in 2002/03) came from the stamp duty on property transfers (see Table 6).

Table 6

Share of Property Taxes in Local Government Revenues in Selected Cities of Punjab

\begin{tabular}{|l|l|l|l|l|l|l|l|l|}
\hline \multirow{2}{*}{} & \multicolumn{3}{|l|}{ Property tax as \% of } & \multicolumn{2}{l|}{$\begin{array}{l}\text { Property transfer tax (stamp duty) as } \\
\text { City of }\end{array}$} \\
\cline { 2 - 9 } & \multicolumn{3}{|l|}{ total taxes } & \multicolumn{2}{l}{ total revenue } & \multicolumn{2}{l|}{ Total taxes } & \multicolumn{2}{l|}{ total revenue } \\
\cline { 2 - 9 } & $\mathbf{2 0 0 1 / 0 2}$ & $\mathbf{2 0 0 2 / 0 3}$ & $\mathbf{2 0 0 1 / 0 2}$ & $\mathbf{2 0 0 2 / 0 3}$ & $\mathbf{2 0 0 1 / 0 2}$ & $\mathbf{2 0 0 2 / 0 3}$ & $\mathbf{2 0 0 1 / 0 2}$ & $\mathbf{2 0 0 2 / 0 3}$ \\
\hline Gujranwalla & $43 \%$ & $38 \%$ & $6 \%$ & $5 \%$ & $57 \%$ & $62 \%$ & $7 \%$ & $9 \%$ \\
\hline Faisalabad & $66 \%$ & $36 \%$ & $7 \%$ & $4 \%$ & $32 \%$ & $61 \%$ & $3 \%$ & $6 \%$ \\
\hline Multan & $25 \%$ & $4 \%$ & $4 \%$ & $2 \%$ & $73 \%$ & $96 \%$ & $11 \%$ & $55 \%$ \\
\hline Rawalpindi & $58 \%$ & $4 \%$ & $10 \%$ & $0 \%$ & $39 \%$ & $91 \%$ & $7 \%$ & $6 \%$ \\
\hline Lahore & $21 \%$ & $12 \%$ & $8 \%$ & $4 \%$ & $79 \%$ & $87 \%$ & $29 \%$ & $27 \%$ \\
\hline Median & $\mathbf{4 3 \%}$ & $\mathbf{1 2 \%}$ & $\mathbf{7 \%}$ & $\mathbf{4 \%}$ & $\mathbf{5 7 \%}$ & $\mathbf{8 7 \%}$ & $\mathbf{7 \%}$ & $\mathbf{9 \%}$ \\
\hline
\end{tabular}

Source: TMA database.

\footnotetext{
${ }^{32}$ Malpezzi and Ball (1991).
} 
90. Reform of property taxation towards more value based tax system would not only generate more revenue for the local governments, but also align the interests of the local governments with those of the business development as increase in the property values would result in an increase in the government's revenue.

91. Due to their significant role in local finances, reforming stamp duties is also not a straightforward and easy task. Nevertheless, Punjab government has made significant improvements in this regard and has reduced its stamp duties from 9 to 5 percent, and fees from 3 to 0.5 percent in 2003 (see Table 7).

Table 7

Stamp Duties and Registration Fees in Punjab (2001)

\begin{tabular}{|c|c|c|c|}
\hline & Stamp duty & Registration fee & Total \\
\hline \multicolumn{4}{|l|}{ SALE } \\
\hline Agricultural land & $4 \%$ & $1 \%$ & $5 \%$ \\
\hline Urban immovable property & $5 \%$ & Rs 50* & $5 \%+\operatorname{Rs} 50$ \\
\hline Other cases than urban property & $4 \%$ & $1 \%$ & $5 \%$ \\
\hline \multicolumn{4}{|l|}{ EXCHANGE } \\
\hline Agricultural land & $\mathrm{n} / \mathrm{a}$ & $1 \%$ & \\
\hline Urban immovable property & $5 \%$ & Rs.50 & $5 \%+$ Rs 50 \\
\hline Other cases than urban property & $4 \%$ & $1 \%$ & $5 \%$ \\
\hline \multicolumn{4}{|l|}{ LEASE } \\
\hline Of immovable property (2004) ${ }^{a}$ & $3 \%$ & $1 \% * *$ & $4 \%$ \\
\hline \multicolumn{4}{|l|}{ GIFT } \\
\hline Agricultural land & $4 \%$ & $1 \%$ & $5 \%$ \\
\hline $\begin{array}{l}\text { Agricultural land in favor of } \\
\text { legal heirs }\end{array}$ & $2 \%$ & $1 \%$ & $3 \%$ \\
\hline Other cases than Urban property & $4 \%$ & $1 \%$ & $5 \%$ \\
\hline $\begin{array}{l}\text { Urban immovable property in } \\
\text { favor of legal heirs }\end{array}$ & $3 \%$ & $1 \%$ & $4 \%$ \\
\hline Other cases than urban property & $4 \%$ & $1 \%$ & $5 \%$ \\
\hline \multicolumn{4}{|l|}{ MORTGAGE } \\
\hline Mortgage deed (2003) ${ }^{b}$ & & $0.25 \%$ & \\
\hline
\end{tabular}

* registration fee is $1 \%$ (World Bank et al 2004).

** in accordance with Revenue Department, Government of Punjab (2001) registration fee was $5 / 8$ of the value of stamp duty (equivalent to $1.875 \%$ ) in 2001.

${ }^{\mathrm{a}}$ World Bank (2004a), ${ }^{\mathrm{b}}$ Aries Group et al (2004).

Source: Revenue Department, Government of Punjab (2001).

92. High stamp duties discourage registration of real estate transactions or reporting their true values, thus, also restricting the full use of the property value. For example, an internally conducted survey by HBFC in 2003 found that 50 percent of property owners own their real estate on the basis of Power of Attorney to avoid high taxation. This also negatively affects government revenues not only from stamp duties, but also from other taxes such as income, sales and property taxes (World Bank 2004a). In contrast, the initial experience in India (Maharashtra, 
Punjab, West Bengal), as well as Pakistan, indicates that lowering stamp duties results in increased rather than decreased government tax revenue. ${ }^{33}$

93. The proposed Punjab Finance Bill for 2004 provided for further reduction in stamp duty on property transactions to 2 percent. $^{34}$ While this would bring Punjab more in line with the other provinces of Pakistan, it still high relative to other countries such as China, Philippines and Singapore. $^{35}$ Other fees are also levied in Punjab, such as those on the registration of rental contracts and change of property use. For example, land commercialization fee is set at 20 percent of the value of the land. ${ }^{36}$

94. Due to low tax revenue the governments have limited resources for provision of infrastructure and services. It has adverse effects on the quality of services and consequently residents' willingness to pay not only service changes, but taxes in general. Thus, distortive taxation policy leads to a vicious circle.

95. As the national government has started to realize the negative implications of its tax policies, it has envisaged significant reductions in stamp duties and fees in the NHP. The government has also established a committee comprising federal and provincial officials to examine the provincial tax regimes and prepare recommendations for their rationalization and reform.

\section{Complex Institutional Framework}

96. The overall responsibility for planning in Punjab has been assigned to Punjab Housing \& Town Planning Agency (PHATA), which prepares the provincial land-use plans as well as Master Plans, Outline Development Plans, Small Town Development Plans and City District/Tehsil/Union Council Plans. ${ }^{37}$ At the same time the Local Government Ordinance of 2001 (LGO) provides for significant devolution of planning responsibilities to the lower levels of the government. Thus, the actual division of functions and responsibilities is not clear.

97. Furthermore, the different levels of local governments are envisaged as independent units under the LGO without any hierarchical administrative linkages. Such a segregated system results in decisions being made independently by each local government / authority and leads to focusing on individual priorities rather than broader systemic infrastructure issues (World Bank 2004a).

98. This fragmentation is generating two very serious problems: First and foremost, service delivery issues across TMAs are ignored. The TMAs have not yet realized that the province will no longer be financing development schemes, so have not adjusted their revenues accordingly.

\footnotetext{
${ }^{33}$ Alm et al (2004) and Ali (2004) for India and Pakistan respectively.

${ }^{34}$ Daily Times (2004). Information on the actual reduction is not available at the time of this study.

35 There is no stamp duty in Islamabad. Registration fee is Rs 150/sq.yard for the transfer of property, which, however, may be quite high depending on the value of property. For example, based on the data in Guitard et al (2004) it may compose $2-39 \%$ of the value of industrial land. In Sindh stamp duty for the transfer of property is $3 \%$ and a fee on mortgage registration is $0.2 \%$. (World Bank et al, 2004; Government of Sindh, 2001). Stamp duties on property transfer, lease and mortgages are less than $0.1 \%$ in China, $0.1-0.4 \%$ in Philippines, $0.4-4 \%$ in Malaysia and 0.4-3\% in Singapore depending on the property value and term of lease (calculated based on Alm et al 2004).

${ }^{36}$ Punjab Rules on Commercialization of Property - http://www.lda.gop.pk/lda cmp.html.

${ }^{37}$ http://www.punjab.gov.pk/hud/PHTA.pdf and http://www.punjab.gov.pk/hud/index.htm.
} 
An important related issue is that TMA budgeting is poor, and medium term budgeting (which is what you do for programing capital investments) is non-existent. Secondly within TMAs, administrations sub-divide their TMA capital budget between union councilors so what is provided in the end is piecemeal infrastructure. In addition, the provincial level zoning and building by-laws are inconsistent across authorities resulting in confusion, conflicting policies and decisions, and lack of coherent set of city-wide approaches. This further reinforces the piecemeal approach to the area development practice.

99. Administration of zoning, building by-laws (e.g. building heights, FARs, etc.), and building approvals are administered by a number of different agencies. For instance, in the case of Lahore, these include the Lahore Development Authority (LDA), Cantonment Board, Defense Colony and Tehsil Municipal Administrations. (World Bank et al 2004) The processing of applications for site development, approval of related plans, and issuance of associated permits is slow and complex, and may take up to a year to complete. The recent firm survey in Pakistan (the Administrative and Regulatory Costs Survey; FIAS, 2005) revealed that 61 percent of respondents are hiring agents to assist them in obtaining site development permits and 57 percent reported paying bribes to expedite the process. The process requires submission of 61 documents and costs Rs 569,000 (US $\$ 9,810^{38}$ ) on average, including Rs 220,000 (US\$ 3,800) in bribes. Obtaining building approval in Lahore may involve up to 18 different intermediate approvals and permits. Site inspections are conducted and development permits issued by numerous authorities. Between site inspections and development permits, a builder/developer could reportedly interface with as many as 15-25 authorities depending on the specific location.

\section{The public sector's response to the affordable housing shortfall has been in ineffective}

100. The Government of Punjab appears to be focusing more on the direct provision of serviced land through housing development schemes rather than promoting an enabling environment that would allow the private sector and individuals to take care of their own needs. Unfortunately, public production of residential plots in the Punjab has been minuscule. Presence of federal government in housing provision is rather limited. There appears to be one federal housing program implemented by the Pakistan Housing Authority (PHA) in Punjab and 4 projects are in operation in Lahore providing 1,240 housing units. There are no requirements for eligibility under the program. All units are allocated on a 'first come - first serve' basis upon down-payment (The government of Punjab had allocated Rs 4.1-4.7 billion (US\$ 70-78 million), or 23-25 percent of its development budget for housing and planning purposes in 2000-02. However, the majority of these resources were allocated for planning purposes, while resources for low income housing and khaki abadis schemes composed less than 2 percent of the total development budget

101. Since 1972, federal, provincial and local production of plots and units totals 215,000 (see Table 8). This works out to about 6,500 plot and units per year on average. ${ }^{39}$ At current rates, the Punjab Province adds about 110,000 households per year. In the best case, assuming that all plots

\footnotetext{
${ }^{38}$ Here and further in the text the average 2003 exchange rate of US\$1 = Rs 58 is used for currency conversions unless indicated otherwise.

${ }^{39}$ However, many of these plots are vacant and lack infrastructure services.
} 
are provided with infrastructure, government agencies account for slightly less than 6 percent of annual household formation.

102. Punjab appears to have fallen into a common trap of "too much government" in the areas of zoning, planning and regulations and "not enough government" in regards of property rights, provision of infrastructure and facilitation of the private sector involvement as described by Dowall and Clark (1996). Experience so far indicates that this approach has not been very successful and has resulted in highly inefficient housing and land markets.

Table 8

Government Housing Programs in Punjab

\begin{tabular}{|c|c|c|c|}
\hline Program & No. of areas & No. of units & Cost (Rs million) \\
\hline 1. PHA schemes & 4 (Lahore) & 1,240 & \\
\hline $\begin{array}{ll}\begin{array}{l}\text { 2. } 3 \text {-marla } \\
\text { housing }\end{array} & \left(75 \mathrm{~m}^{2}\right) \\
\text { (PHATA) } & \text { scheme } \\
\end{array}$ & 22 (19 completed) & 13,495 & \\
\hline 3. ADS (PHATA) & 110 & $\begin{array}{l}104,818 \\
\text { completed }\end{array}$ & 13,922 \\
\hline 4. ADS (LDA) & Lahore & $88,662 * *$ & \\
\hline $\begin{array}{l}\text { 5. Katchi } \quad \text { Abadis } \\
\text { Development Program }\end{array}$ & 29 locations & & $\begin{array}{l}150 \text { (allocated for } \\
2002 / 03 \text { ) }\end{array}$ \\
\hline $\begin{array}{l}\text { 6. Housing for Pakistani } \\
\text { Expatriates* }\end{array}$ & 9 cities & 6,600 & $\begin{array}{l}\text { Costs }-1,870 \\
\text { Revenues }-2,637\end{array}$ \\
\hline $\begin{array}{l}\text { 7. Housing for the } \\
\text { Government Servants }\end{array}$ & $\begin{array}{l}\text { Throughout Punjab, pilot } \\
\text { in Mohlanwal (Lahore) }\end{array}$ & & $\begin{array}{l}79 \text { in } 2000 / 01 \text { and } \\
150 \text { in } 2001 / 02\end{array}$ \\
\hline
\end{tabular}

* Announced, not implemented yet.

** LDA has implemented 21 housing schemes that provided 71,258 plots (Word Bank 2004b).

Source: www.pha.gov.pk and www.punjab.gov.pk

103. In order to better assess the effectiveness, costs and benefits of the different programs more information is needed. However, experience in other countries indicates that public housing and land development, and slum up-grading programs are generally less effective in addressing housing and land shortages than elimination of the numerous restrictions on the housing and land markets (Bertaud 1989).

104. Furthermore, a number of studies ${ }^{40}$ show that in-kind subsidies such as allocation of land and housing at sub-market prices and provision of free infrastructure introduce large inefficiencies because usually the value of the asset to the recipient is lower than the cost of its provision to the government. This results in strong incentives for speculation and resale of property. The extent of the inefficiencies is closely related to the size of the subsidy and elasticity of housing substitution for other goods, and was estimated by Aaron and von Furstenberg (1971) at 8-60 percent depending on the size of the subsidy. At the same time limiting the occurrence of resale usually requires extensive and costly government controls.

\footnotetext{
${ }^{40}$ Aaron and von Furstenberg (1971), Bradford and Shaviro (1999), Friedman and Weinberg (1982).
} 
105. In-kind subsidies such as subsidized low income housing projects also tend to reduce residential mobility of the poor as the subsidy is tied to the location (Bertaud, 2004). While well designed government assistance would be necessary to ensure adequate housing supply for low income groups, addressing the policy constraints is crucial for the market to be able to cater to the needs of the higher and middle income groups. A detailed analysis of the costs and benefits to the developers and buyers in Malaysia showed that the costs imposed by regulatory constraints by far outweighed the benefits of land and tax subsidies. ${ }^{41}$ As a result, the increasing demand caused increase in prices rather than supply.

106. Based on the experience so far and the ever increasing demand for housing and developed urban land it is clear that the government will not be able to address the needs through direct interventions in the market and other means will be necessary. One of the important aspects is facilitation of greater involvement of private industry. Therefore, understanding the regulatory constraints to more robust private sector engagement in real estate development is a critical part of the analysis.

\footnotetext{
${ }^{41}$ For detailed analysis see Malpezzi and Mayo (1997), Bertaud and Malpezzi (1994) and World Bank (1989a).
} 


\section{Recommendations}

107. The key conclusion of the study is that increasing urbanization and economic development are imposing ever greater pressures on the housing and land markets in Punjab. However, the observable market characteristics such as rapidly rising property prices and housing expenditures, large informal settlements, limited investment in housing and small formal mortgage markets indicate significant potential distortions. This Background Study has pinpointed a range of impediments, including: excessive public land ownership, inadequate infrastructure services, weak property rights, counterproductive urban planning policies and regulations, costly subdivision and construction regulations, limited financing for property development and acquisition, rent controls and distortive taxation mechanisms. In this section we outline a range of recommendations for improving urban land and housing market performance.

108. Our recommended approach is based on the notion that the reform agenda should be comprehensive, and coherently link together the full range of needed actions. As demonstrated by Galal and Razzaz (2001) the absence of a comprehensive approach or a "road map" to guide the design of reforms often produces reforms that focus too narrowly on a single issue such as land registration, mortgage finance or slum regularization. While such reforms provide positive results, their impact and sustainability can be undermined by distortions in other areas. Thus, achievement of desired benefits and more efficient housing and land markets require a comprehensive approach to the reforms. However, since it is not possible to launch all reforms at the same time, prioritization and sequencing are important. Furthermore, "successful implementation requires more than just issuing new laws or regulations. It requires changes in incentives, institutions and behaviors." (Galal and Razzaz, 2001) Furthermore, any reforms require political commitment. Some are quicker and easier and some are more longer term and require preparatory steps.

\section{Recommendation 1: Build an urban information base and deepen understanding of urban land and property market dynamics.}

The reform agenda must be guided by sound and accurate information on the patterns of urban land development, land prices, land supply, number of housing units built (both formal and informal), rents and their trends (including residential and non-residential), data on current and future development projects. Economic and demographic surveys and studies are needed to make projections of future urban growth and resulting land market requirements. Dowall (1995) provides a detailed framework for such a land market assessment.

Availability of good market information would also provide great benefits for the property developers. For example, the results of a land market assessment in Bangkok (Dowall, 1995) in 1987 revealed that low cost housing units had much higher demand than the overall housing market. As a result, developers realized the potential profitability in this market segment. 
Recommendation 2: Strengthen property rights and improve efficiency of land titling and registration.

With respect to the formal sector, reform initiatives should focus on closing loopholes in the property registration, including elimination of legal protection of unrecorded transactions; reorganizing property registration system to ensure effective protection of property rights - up-dating records, merging and computerizing databases; and streamlining the interface with the public establishing easy access to "one-stop-shops" for obtaining information on property rights.

For informal areas with problematic land rights and titles, a comprehensive approach to regularizing informal settlements should be framed. A number of countries have successfully introduced different instruments with varying degrees of tenure security. Those can be in the form of legally recognized rights of use provided to the squatter and slum dwellers, while the ownership of the land stays with the original owner (e.g. Certificates of Rights in Botswana and Concession of the Real Right to Use in Brazil). Another approach is provision of titles through a separate dedicated mechanism as was the case under COFOPRI program in Peru, where one million titles were issued to residents of informal settlements over 5 year period. (GPA, 2001).

\section{Recommendation 3: Reform and restructure systems of local property taxation to reduce distortions and to strengthen resource mobilization.}

The current asymmetry between local resources and local infrastructure and urban service requirements is enormous and must be corrected. Reforms are needed to improve the efficacy and efficiency of property tax mechanisms and government should look for alternative tools for financing infrastructure and urban service delivery.

Recommendation 4: Reform urban planning, zoning, subdivision and construction regulations to encourage sound economic development of cities and more affordable housing production.

First and foremost, urban master plans and zoning ordinances need to be revised to better align urban land supply with market demands. Plans should be developed based on more careful and rigorous analysis of future development trends. Assessed through market studies rather than perceived "need" based on demographic trends. This would allow planners to explicitly consider economic as well as social, environmental and physical implications of alternative master plans and zoning. 
Second, floor area ratios and other development controls should be reviewed and revised and include increasing the FARs, particularly towards the CBD.

Third, reforms should include reviews of existing planning and subdivision standards and building codes and making required adjustments to ensure their affordability, while taking into consideration social and environmental aspects.

\section{Recommendation 5: Reform rent control.}

It may vary from a 'shock therapy' of elimination of all rent controls at once to a gradual deregulation through exemption of new construction, more frequent and more market led rent increases and other measures. This may also entail the replacement of rent control with well targeted housing subsidies such as housing allowances, vouchers, etc., which have been applied in the USA, Chile, Armenia, Latvia and other countries

Recommendation 6: Reduce levels of public land ownership through auctions and use proceeds to finance critical infrastructure and engage in a reform of public land development agencies.

An initial step would be to conduct a comprehensive survey of public land ownership in Punjabi cities. Holdings should be evaluated for potential development. High value sites should be auctioned off and the proceeds used to finance infrastructure.

At the same time, the Government of Punjab should undertake a through assessment of the performance of public land development agencies and undertaking the necessary adjustments. Those may include restructuring, full or partial privatization, liquidation of agencies as well as auctioning of public land holdings and concentrating on provision of infrastructure. ${ }^{42}$

\section{Recommendation 7: Increase investment in infrastructure systems and build institutional base for economically and financial sustainable system of infrastructure delivery, operations and maintenance.}

Based on new master plans and economic development strategies, Punjabi cities should develop capital investment plans for infrastructure projects. These plans should also include business plans for operating and maintaining systems as well as recovering capital costs.

A collateral activity will be to identify and design new financing mechanisms for paying for new infrastructure. These mechanisms might include reforming

\footnotetext{
${ }^{42}$ For some guiding principles, see Dowall and Clark (1996).
} 
property taxation to align it with actual property values; and introducing development impact or and betterment fees as well as other land value capture instruments.

Recommendation 8: Encourage more private sector participation in real estate development and the financing of real estate.

The Punjab needs to increase the involvement of the private sector in land and real estate development and provision of infrastructure. This will require regulatory reforms, enhanced access to real estate finance, and access to land for real estate development, training and professional development.

Recommendation 9: Design new institutional frameworks for managing urban development at the local, city and metropolitan levels.

An overall assessment of the current institutional and organization framework for land and housing and devolving land management should be undertaken and reforms made to improve coordination and effectiveness at local, city and metropolitan levels of governments.

109. As the governments of Pakistan and Punjab focus attention on the looming challenges posed by rapid urban development, reform efforts should be closely coordinated at the central, provincial and local levels of government. Governments at all levels should focus on the establishment of an enabling environment through strengthening the legal framework, particularly, for property rights, modernizing its planning, zoning and construction regulations and approaches, withdrawal from direct interventions in the market and facilitating greater involvement of the private sector. 


\section{References}

Aaron, Henry J. and George M. Von Furstenberg. 1971. The inefficiency of transfers in kind: the case of housing assistance. Western Economic Journal.

ADB. 2001. Cities Data Book: Asia and Pacific Region. Presentation at the dissemination $\begin{array}{llll}\text { workshop } & \text { on } & \text { February } & 15-16,\end{array}$ http://www.adb.org/Documents/Events/2001/Cities_Data_Book/default.asp

ADB. 2003. Report and Recommendation of the President to the Board of Directors on Proposed Loans to the Islamic Republic of Pakistan for the Southern Punjab Basic Urban Services Project. http://www.adb.org/Documents/RRPs/PAK/rrp_pak_23213.pdf

Alm, James, Patricia Annez and Arbind Modi. Stamp Duties in Indian States. A Case for Reform. 2004. Word Bank. Washington D.C.

Aries Group in association with Mandviwalla \& Zafar and M Yousuf Adil Saleem \& Co. 2004. Feasibility Study for Establishing a Secondary Mortgage Market Entity in Pakistan. Unpublished.

Benton, Lauren A. 1987. Reshaping the Urban Core: the Politics of Housing in Authoritarian Uruguay. Latin American Research Review, vol. 22.

Berger-Thomson, Laura and Luci Ellis. 2004. Housing Construction Cycles and Interest Rates. Research Discussion Paper 2004-08. Reserve Bank of Australia. http://www.rba.gov.au/rdp/RDP2004-08.pdf

Bertaud, Alain. 1989. The Regulatory Environment of Urban Land in Indonesia: Constraints Imposed on the Poor and Impact of World Bank's Urban Projects. http://alainbertaud.com/images/Indonesia_regulatory\%20environment_AB2.pdf

Bertaud, Alain. 2002. The economic impact of land and urban planning regulations in India. A Memorandum on Urban Land Issues in India. April 11, 2002.

Bertaud, Alain. 2004. The spatial organization of cities: Deliberate outcome or unforeseen consequence? bertaud.com/images/AB_The_spatial_organization_of_cities_Version_3.pdf

http://alain-

Bertaud, Alain and Jan K. Brueckner. 2003. Analyzing Building-Height Restrictions: Predicted Impacts, Welfare Costs, and a Case Study of Bangalore, India. http://alainbertaud.com/images/bangalore_FSI_Bertaud_Brueckner.pdf

Bradford, David F. and Daniel N. Shaviro. 1999. The Economics of Vouchers. National Bureau of Economic Research, USA.

Census Organization of Pakistan. 1998. Fifth Population and Housing Census. Islamabad.

Cheshire, Paul and Stephen Sheppard. 1995. On the Price of Land and the Value of Amenities. Economica 62, p.247-267.

Cheshire, Paul and Stephen Sheppard. 2002a.Welfare Economics of Land Use Reuglation. Journal of Urban Economics 52, p. 242-269.

Cheshire, Paul and Stephen Sheppard. 2002b. Capitalizing the Value of Free Schools: the Impact of Land Supply Constraints. Lincoln Institute of Land Policy Conference Paper CP02A08.

Cheshire, Paul and Stephen Sheppard. 2004. Land Markets and Land Market Regulation: Progress towards Understanding. Regional Science and Urban Economics 34, p. 619. 637.

Daily Times (Pakistan). 2004. Proposed taxation measures for 2004-05. Daily Times December 25, 2004. http://www.dailytimes.com.pk/default.asp?page=story_18-6-2004_pg1_6 
Dawn. 2004. Lahore: 35,000 residential plots to be developed in five years. Dawn. The Internet Edition of October 22, 2004. www.dawn.com/2004/10/22/local 14.htlm.

Dowall, David E. 1991a. A Comparison of Karachi's Informal and Formal Housing Delivery Systems. Cities (August).

Dowall, David E. 1991b. The Karachi Development Authority: Failing to Get the Prices Right. Land Economics.

Dowall, David E. 1992. A Second Look at the Bangkok Land and Housing Market. Urban Studies 29, p. 25-37.

Dowall, David E. 1995. The Land Market Assessment. A New Tool for Urban Management. Urban Management Program. World Bank, Washington D.C.

Dowall, David E. 1998. Making Urban Land Markets Work: Issues and Policy Options. University of California, Institute of Urban and Regional Development, Berkeley.

Dowall, David E. 2004. Managing Urban Land to Achieve Strategic Development Objectives. Presentation to the World Bank on November 2, 2004.

Dowall, David E. and Giles Clark. 1996. A Framework for Reforming Urban Land Policies in Developing Countries. World Bank, Washington D.C.

Dowall, David E. and Michael Leaf. 1991. The Price of Land for Housing in Jakarta. Urban Studies 28, p. 707-722.

D’Souza, Conrad. 2003. Presentation at the Housing Finance Seminar in Karachi in August 2003.

Economist 30 March 2002.

Feldman, Elliott, Michael A Goldberg. 1995 Land rites and wrongs: the management, regulation, and use of land in Canada and the United States. Boston OGH, 1988.

FIAS. 2005a. Review of Administrative Barriers to Investment. Draft of May 2005. World Bank.

FIAS. 2005b. Improving the Performance of the Housing, Tourism and Retail Sectors in Pakistan. World Bank.

Friedman, Joseph, Emmanuel Jimenez and Stephen K. Mayo. 1988. The Demand for Tenure Security in Development Countries. Journal of Development Economics, vol. 29.

Friedman, Joseph and Daniel H. Weinberg. 1982. The Economics of Housing Vouchers. Academic Press.

Galal, Ahmed and Omar Razzaz. 2001. Reforming Land and Real Estate Markets. Policy Research Working Paper 2616. World Bank, Washington D.C.

Gibbons, Steve. 2002. The Cost of Urban Property Crime. Lincoln Institute of Land Policy Conference Paper CP02A02

Government of Pakistan. Interim Poverty Reduction Strategy Paper.

Government of Punjab 2006. Planning and Development Board.

Government of Sindh. 2001. Finance Ordinance (No. XXIII of 2001). The Sindh Government Gazette, June 30, $2001 . \quad$ Karachi. http://www.paksearch.com/Government/TAX/SROs/Miscellaneous/2001/MIS-FNO3.htm

GPA (Geoffrey Payne and Associates). 2001. Innovative Approaches to Secure Tenure for the Urban Poor. Hastings Printing Company. 
Guitard, Philippe, Shahid Ahmed Khan and Derk Bienen. 2004. New Business Opportunities in Pakistan: An Investor's Guidebook. European Union Asia Investment Program. http://www.fisme.org.in/Opportunities\%20Pakistan.pdf

Hammam, Sonia and Somik V. Lall. 2005. Dimensions of Property Taxation in Indian Cities. Presentation at the World Bank on March 8, 2005.

Hasan, Syed Ali Dayan. 2001. The Punjab is Another Country. The Herald. Special Lifestyles Edition. June 13-15, 2001.

Hilber, Christian Al and Christopher J. Mayer. 2001. Land Supply, Price Capitalization, and Local Spending on Schools. Wharton School Real Estate Department Working Paper, Nov 2001.

Ihlanfeldt, Keith R. and Timothy M. Shaughnessy. 2004. An empirical Investigation of the Effects of Impact Fees on Housing and Land Markets. Regional Science and Urban Economics 34, 619-637.

Jiang, Dianchun, Jean Jinghan Chen and David Isaac "The Effect of Foreign Investment on the Real Estate Industry in China," Urban Studies. Volume 35, Number 11 / November 1, 1998, pp. 2101-2110.

Jimenez, Emmanuel. 1984. Tenure Security and Urban Squatting. The review of Economics and Statistics 66 (4), p. 556-567.

Jimenez, Emmanuel. 1988. The Demand for Tenure Security in Developing Countries. Journal of Development Economics 29.

Kim, Kyung-Hwan. 1991. Housing Prices, Affordability, and Government Policy in Korea. Asia Regional Series, Report No. IDP 99. World Bank, Washington D.C.

LDA (Lahore Development Agency). 2004. Integrated Master Plan for Lahore. Presentation by LDA.

Lin, Chu-Chia, Chao-Cheng Mai and Ping Wang. 2003. Urban Land Policy and Housing in an Endogenously Growing Monocentric City. Regional Science and Urban Economics. Elsevier Science B.V. http://www.sciencedirect.com/science/article/B6V89-48M7TRD1/2/b0baedbcdb1890a06026980c416453e5

MacLennan, Duncan. 1986. Maintenance and Modernization of Urban Housing. OECD Urban Affairs Program.

Mahmood, Azhar. 2004. LCH Slaps Strict Terms on Pak Banks. Business News. February 15, 2004. www.jang.com.pak/thenbews/feb2004-daily/15-02-2004/business/b3.htm

Malpezzi, Stephen and Gwendolyn Ball. 1991. Rent Control in Developing Countries. World Bank. Washington D.C.

Malpezzi, Stephen and Stephen K. Mayo. 1997. Getting housing incentives right: a case study of the effects of regulation, taxes and subsidies on housing supply in Malaysia. Land Economics 73(3), p. 372-391.

Ministry of Housing and Works of Pakistan. 2001. National Housing Policy.

Ministry of Planning, Government of Pakistan 2006. Vision 2030.

Ministry of Water and Power of Pakistan, Office of the Chief Engineering Advisor / Chairman Federal Flood Commission. 2002. Pakistan Water Sector Strategy: National Water Sector Profile, Volume 5. http://www.waterinfo.net.pk/pdf/vol5.pdf

NMHC (National Multi-Housing Council). 1996. The High Cost of Rent Control. http://www.nmhc.org/Content/ServeContent.cfm?IssueID=66\&ContentItemID=1186 
Ohls, James, Richard Weisberg and Michelle White. 1974. The Effects of Zoning on Land Value. Journal of Urban Economics 1, p. 428-444.

Pakistan Federal Bureau of Statistics. 2001. Pakistan Demographic Survey - 2001. http://www.statpak.gov.pk/depts/fbs/statistics/pds2001/table01.pdf

Pakistan Federal Bureau of Statistics. 2001/02. Household Integrated Economic Survey 2001-02.

Pakistan Federal Bureau of Statistics. 2004. Pakistan Statistical Year Book 2004.

Pollakowski, Henry O. 1997. The Effects of Rent Deregulation in New York City. Massachusetts Institute of Technology Center for Real Estate, Cambridge, MA (USA).

Pollakowski, Henry O. 1999. Rent Regulation and Housing Maintenance in New York City. Massachusetts Institute of Technology Center for Real Estate, Cambridge, MA (USA).

Pollakowski, Henry O. 2003. Rent Control and Housing Investment: Evidence from Deregulation in Cambridge, Massachusetts. Center for Civic Innovation at the Manhattan Institute, New York, NY (USA).

Rakodi, Carole. 1989. The Production of Housing in Harare, Zimbabwe: Components, Constrains and Policy Outcomes. Trialog, vol 20.

Revenue Department, Government of Punjab. 2001. http://www.punjab.gov.pk/bor/revenue/stamps.htm

Simon, Alison. 1995. Sequencing Infrastructure Development in the Barrios Marginales of Quito, Ecuador: Policy Findings of a Hedonic Price Model. Ph.D. dissertation, Department of Urban and Regional Planning, University of Illinois at UrbanaChampaign.

UN-HABITAT. 1989. Strategies for Low-income Shelter and Services Development: the RentalHousing Option. UN-HABITAT. Nairobi. http://www.unhabitat.org/programmes/housingpolicy/documents/HS-172.pdf

Thorsnes, Paul. 2000. Internalizing Neighborhood Externalities: the Effect of Subdivision Size and Zoning on Residential Lot Prices. Journal of Urban Economics 48 (3), p. 397-418.

Weist, Dana. 2005. The Challenge of Urban Finance and Governance in India: findings from Three Indian States. Presentation at the World Bank on January 27, 2005.

World Bank. 1989a. Malaysia. The Housing Sector. Getting the Incentives Right. World Bank, Washington D.C.

World Bank. 1989b. Shelter Sector Review in Pakistan. World Bank, Washington D.C.

World Bank. 2002a. A Housing Finance System for Pakistan. Issues and Options. June 7, 2002. PK-Pakistan Housing Finance Project-P084949.

World Bank. 2002b. Pakistan Development Policy Review: A New Dawn? World Bank, Washington D.C.

World Bank. 2003a. East Asia and Pacific: Urban Business Directions.

World Bank. 2003b.Aid Memoire. Housing Finance Project mission in September 2003.

World Bank. 2004a. Punjab Urban Sector Policy Review Mission (May 31-June 10, 2004) AideMemoire. Unpublished.

World Bank. 2004b. Lahore Review Mission (October 10-16, 2004) Aide-Memoire. Unpublished.

World Bank. 2005a. Aid Memoire of June 12 - 24, 2005. Land Records Management and Information Systems Program (Province of Punjab).

World Bank. 2005b. Project Information Documents. Land Records Management and Information Systems Program (Province of Punjab).

World Bank 2006. Development Data Platform. 
World Bank, ADB and Department for International Development (UK). 2004. The Punjab Economic Report: Towards a Medium-Term Development Strategy. Discussion draft of June 28, 2004. 


\section{Laws / regulations}

1. Acquisition of Land (Housing) Act, 1973 (Punjab)

2. Benami Act (Pakistan)

3. Disposal of Land by Development Authorities (Regulation) Act, 1998 (Punjab)

4. Katchi Abadis Act, 1992 (Punjab)

5. (Land) Registration Act, 1908 (Pakistan)

6. LDA Terms and Conditions of Auctions:

i) Residential and Commercial Plots

ii) Lease Rights of Petrol Pump Sites

iii) Lease Rights of Bays under Bridger

iv) Lease Rights of Parking Areas

v) Lease Rights of Agricultural Land

7. Local Government Ordinance, 2001 (Punjab)

8. Policy for Extension in Building Period of October 19, 1993 (Punjab)

9. Policy for Disposal of Public Utility Plots / Sites of September 16, 1999 (Punjab)

10. Punjab Housing and Town-planning Agency Ordinance, 2002

11. Punjab Urban Rent Restriction Ordinance, 1959

12. Stamp Act, 1899 (Pakistan)

13. Transfer of Property Act, 1882 (Pakistan) 